\title{
Om analyse af stavefejl. Årsager, korrespondensregler og udtalevariation
}

\author{
HOLGER JUUL OG JAN HEEGÅRD PETERSEN
}

\begin{abstract}
Artiklen viser hvordan man kan analysere stavefejl på en pædagogisk relevant måde, og den peger på nødvendigheden af at inddrage viden om udtale. Artiklen skelner grundlæggende mellem to årsager til stavefejl: normkonflikter og normhuller. Afvigelser fra distinkt rigsmålsudtale kan give anledning til normkonfliktfejl, mens manglende viden om lyd-skrift-korrespondenser kan give anledning til normhulsfejl. Normhulsfejl opdeles i fire typer alt efter om de vedrører ubetingede regler, lydlige betingelser, grammatiske betingelser eller leksikalske betingelser. Præsentationen af årsagstypologien og korrespondensreglerne følges op af en oversigt over nyere udtaleudviklinger i dansk og en diskussion af om det er blevet sværere at lære at stave. Artiklen slutter med en kort diskussion af de politiske, teknologiske og pædagogiske muligheder for at gøre det lettere at stave på dansk.
\end{abstract}

EMMEORD: sprognormer, korrespondensregel, ortografi, lydudvikling, normbrud

\section{INTRODUKTION}

At skrive en tekst kræver helt grundlæggende at man kan gengive ordene i en form så de kan genkendes af modtageren. Stavefærdighed er set i dette perspektiv en akademisk grundfærdighed på niveau med læsefærdighed. Når man som dansklærer skal hjælpe sine studerende eller elever med at blive bedre til at skrive, er det en del af opgaven at indkredse hvad de har brug for at lære om stavning - og at hjælpe dem med at lære det. Derfor er det en vigtig lærerkompetence at være opmærksom på stavefejl og at kunne gennemskue hvad de kan skyldes. Fejl med forskellige årsager må med Paul Diderichsens ord "vurderes, korrigeres og forebygges hver på sin måde" (Diderichsen 1968: 153). 
Det pædagogiske arbejde med afvigelser fra normeret retskrivning (som normeret i Dansk Sprognævns Retskrivningsordbogen, herefter RO) finder sted på alle uddannelsesniveauer i Danmark, og artiklen henvender sig principielt til undervisere i dansk på alle disse. Den udtalebaserede tilgang til stavefejl som vi gennemgående betoner, vil dog nok især være relevant i grundskolen og i ungdomsuddannelser, og derfor taler vi primært om larere og elever (frem for undervisere og studerende). Sigtet med artiklen er ikke at tilbyde en guide til skudsikker analyse af enhver stavefejl man måtte støde på, men at fremstille nogle overordnede linjer og udviklinger. Vores ærinde er således ikke at evaluere eller forbedre de allerede eksisterende rettevejledninger og fejltypologier, men derimod at give overblik over hvad man som staveunderviser har brug for at vide om dansk udtale og ortografi hvis man vil arbejde kvalificeret med stavefejl, herunder at tilbyde den rette pædagogik.

Efter vores opfattelse er det især tre områder som man har brug for viden om, og artiklens formål er at tilbyde en samlet fremstilling af dem. For det første har man brug for viden om hvilke årsager der principielt kan ligge bag stavefejl, og om hvad der overhovedet ligger i begrebet stavefejl. For det andet har man brug for viden om de korrespondensregler der forbinder det talte og det skrevne sprog. Og hvis man skal kunne udpege årsager til stavefejl og opstille korrespondensregler, har man for det tredje brug for viden om variationen i de udtaler som danske skriftsprogbrugere kan tage udgangspunkt $\mathrm{i}$, herunder viden om igangværende udtaleudviklinger i moderne dansk.

I de følgende afsnit behandler vi hvert af de tre nævnte områder. Derefter følger en sammenfatning som kort beskriver den indbyrdes relation mellem dem. Endelig diskuterer vi i artiklens sidste del om og hvordan det kan blive lettere at undgå stavefejl.

\section{2 ÅRSAGER TIL STAVEFEJL}

\subsection{Fejltypologiers begransninger}

Som lærer må man først og fremmest være interesseret $\mathrm{i}$ at indkredse hvad der har forårsaget en stavefejl, sådan at man kan give sine elever den mest relevante støtte. Et første skridt kan være at klassificere fejlene i forhold til en fejltypologi, men man når sjældent i mål ad den vej. Det er der flere grunde til. 
1. De fejltyper der er anvendt i undersøgelser af stavefejl (fx Noesgaard 1945, Uddannelsesstyrelsen 2002), er ofte baseret på sammenligninger af stavefejlens og den korrekte stavemådes bogstaveringsmæssige lighed - jf. fejltyper som fordoblingsfejl ( $\mathrm{fx}$ "kase" for kassel) og r-fejl (fx "katofler" for kartofler og "hun høre" for hun hører). Det kan være nyttigt nok, men sådanne fejltypebetegnelser udpeger ikke fejlenes mulige årsager.

Andre fejltyper har betegnelser der peger på en årsag som imidlertid ikke forekommer særlig sandsynlig. Eksempelvis angiver betegnelsen vokalforveksling ( $\mathrm{fx}$ "gest" for gast, Noesgaard 1945) at skribenten må have taget fejl af to mulige vokalstavemåder, den korrekte og en forkert. Det kan imidlertid lige så vel være tilfældet at staveren slet ikke kendte den korrekte stavemåde, og i så fald er betegnelsen forveksling misvisende. Betegnelsen bruges da typisk også i rent beskrivende forstand, synonymt med betegnelsen vokalerstatning (Detlef m.fl. 1986). På samme måde forekommer det misvisende at omtale "enlig" for egentlig som en ordforveksling når det i sammenhængen ikke er tvivl om at det er ordet egentlig der er intenderet. Endvidere kan man se stavefejl som "tuer" for ture omtalt som en bogstavombytning. Her forekommer det nok så sandsynligt at tasterne er ramt i forkert rækkefølge ved et rent teknisk uheld, sådan at det er tasteanslagene snarere end selve bogstaverne der er byttet om. Slåfejl kan sjældent udelukkes helt som årsagsforklaring, og slet ikke når der er tale om nabobogstaver på tastaturet.

2. Bag samme formelle fejltype kan der ligge helt forskellige årsager. Eksempelvis kan r-fejl dække over fejl der i det ene tilfælde skyldes staverens udtale, fx "katofler" for kartofler i overensstemmelse med udtalen [ka't $\Lambda f l e],{ }^{2}$ og som i det andet tilfælde skyldes manglende opmærksomhed på kravet om nutids-r på

1 Vi anfører stavefejl i citationstegn og korrekte stavemåder i kursiv.

2 Når vi gengiver ord i lydskrift, benytter vi lydskriften IPA og med samme notationskonventioner som anvendes i Heegård Petersen m.fl. (2021). Citater af udtaleangivelser fra andre kilder, fx Den Danske Ordbog, er for at undgå forvirrende inkonsekvenser også omsat til denne lydskriftkonvention. 
verber i skriften (fx "Hun høre" for Hun hører; fx Juul 2003). Et andet eksempel er når kategorien Vokaler $i$ ordstammer hos Rathje (2019) omfatter både lydstridige stavefejl som "gær" for gør og lydbevarende stavefejl som "for" for fär (tryksvagt verbum), hvor digraferne or og år begge kan repræsentere udtalen $[\Lambda]$.

3. Uanset hvor fintmasket en fejltypologi man opstiller, vil der være fejl der kan kategoriseres på flere måder. Eksempelvis diskuterer Rathje (2019) om stavefejlen "referer" for refererer skal placeres som en modusfejl (imperativform anvendt i stedet for præsensform) eller som en stavelsesreduktion. Dette eksempel viser at man ikke altid kan gennemføre en stringent kategorisering og først derefter gå i gang med at fortolke. Den meningsfulde kategorisering forudsætter ofte at man inddrager sine (måske forkerte) formodninger om årsager. I det nævnte tilfælde vælger Rathje kategorien stavelsesreduktion som den mest sandsynlige. ${ }^{3}$

\subsection{En årsagstypologi}

At årsager til stavefejl ikke kan identificeres ud fra en mekanisk fejlkategorisering, bør naturligvis ikke afholde læreren fra at lede efter årsagerne. I det følgende gennemgår vi tre grupper af mulige årsager (se figur 1). Det gør vi med brug af termerne normkonflikt, normbul og normsammenbrud, som vi har lånt fra den svenske sprogforsker Ulf Teleman (Teleman 1981).

Normkonfliktfejl er fejl der skyldes at en skribent tager udgangspunkt $i$ en anden sprognorm end den som retskrivningen typisk ligger tættest på, nemlig et konservativt og distinkt rigsmål - altså en konflikt mellem to udtalenormer. Normhulsfejl er fejl der skyldes et 'hul' i skribentens viden om de korrespondensregler der forbinder udtalenormen med retskrivningsnormen. Og normsammenbrudsfejl er fejl der skyldes

3 Rathje (2019) og senere Holsting m.fl. (2021) benytter en fejltypologi der er overtaget fra sprogforskeren Jørgen Schack, og som er baseret på retskrivningsreglerne; det har den praktiske fordel at fejltyperne peger på de retskrivningsregler som staveren måske har brug for at lære. Den hyppigst forekommende kategori i Rathjes materiale har imidlertid navnet Ikke omfattet af retskrivningsreglerne, hvilket tyder på en vis begrænsning i systemets anvendelighed. 
at skribenten mangler rutine, opmærksomhed eller omhu - og her er det strengt taget ikke en norm der bryder sammen, men vi har valgt at bibeholde Telemans betegnelse. ${ }^{4}$

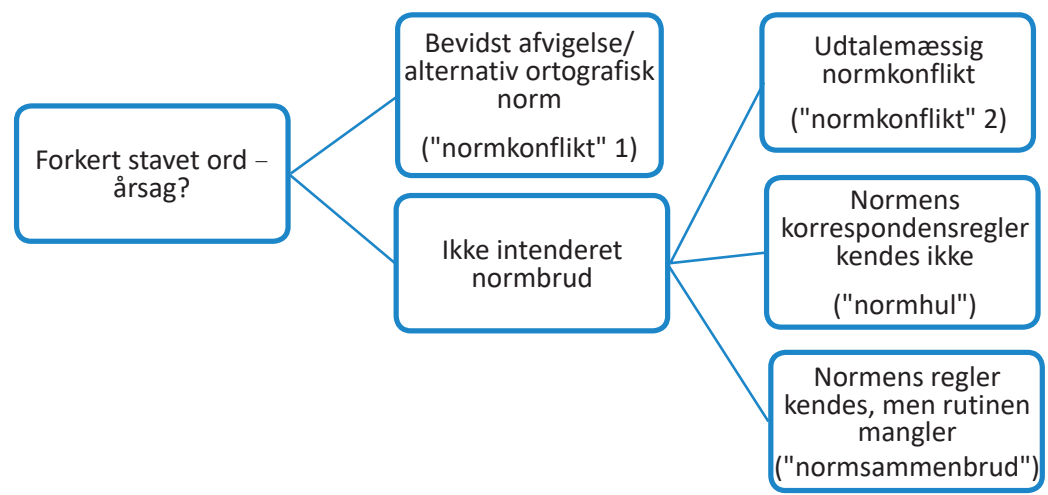

FIGUR 1. OVERSIGT OVER MULIGE ÅRAGER TIL STAVEFEJL ELLER ORTOGRAFISKE NORMBRUD

\subsubsection{Normkonflikt 1: Bevidst afvigelse}

Når man skal forstå hvad der ligger bag et forkert stavet ord, kan man for det første overveje om der er tale om en bevidst afvigelse fra RO's norm. I så fald er betegnelsen stavefejl misvisende da stavemåden jo ikke er en fejl, men et bevidst valg fra skribentens side. Der kan være tale om et politisk statement, som i følgende sætning fra bogen Degte på dansg (Christiansen 1980):

(1) VæmFaen sir jar sga sgrivve sårm a én æler anen skide AKADEMIGGER komanderer mar tse - ?

4 For en udvidet beskrivelse af typologien, der også kan udvides til at omfatte andre typer af normafvigelser i såvel skrift som tale, henviser vi til Teleman (1981). Tanken bag Telemans typologi, der forsøger at sætte ord på årsagen til sprogfejlene, finder man også i Diderichsens fejltyper (1968: 151-152). Til Telemans normkonfliktfejl svarer nogenlunde Diderichsens stilblanding, uhensigtsmassigt sprog og sproglige nydannelser. Svarende til Telemans normhulsfejl har Diderichsen ukyndighedsfejl og afvigelser fra kunstig normalisering. Og svarende til hvad der kan høre til normsammenbrudsfejl, har Diderichsen distraktionsfejl. En kritisk diskussion af Telemans typologi gives af Gregersen (1983). 
Bevidste normbrud kan også forekomme hos sprogbevidste skribenter der justerer på hjørner af retskrivningen, som når forfatteren Palle Lauring skriver "tar" (for tager) og "blie" (for blive), og de kan naturligvis forekomme når en skribent ønsker at gengive en bestemt udtale (fx "war" for en jysk udtale af var; Sørensen 2007, Westergaard 2014, Monka 2018, Larsen \& Stæhr 2020). Endvidere kan uautoriserede stavemåder blive brugt som stilistisk virkemiddel (fx "quinde" for kvinde) eller som del af en virksomheds branding ( $\mathrm{fx}_{\mathrm{x}}$ cafenavne som Bankeråt, Märkbar og Raadhuus Kaféen). Børn i indskolingen opfordres ofte til blot at skrive de lyde de kan høre, uden at bekymre sig om korrekte stavemåder (såkaldt børnestavning; Bjerre og Friis 2002). Og på de sociale medier og i sms-sprog kan der opstå alternative normer med "knuz" for knus som et velkendt eksempel (Rathje 2013, 2019, Andersen 2016).

Man rammer ved siden af hvis man behandler normafvigelser som de nævnte som fejl der bare skal rettes. Det er nærmere refleksion over formålet med at følge en fælles norm der er brug for, herunder valget mellem konkurrerende normer, henholdsvis den gældende og den som den 'oprørske' skribent følger.

\subsubsection{Normkonflikter 2: Udtalemessig normkonflikt}

En anden type normkonflikt forekommer når staveformen afspejler en forskel i opfattelsen af hvad det er for udtaler der skal gengives. Denne type normkonflikter kan $\mathrm{fx}$ være knyttet til regionale udtalenormer, $\mathrm{fx}$ "glaj" for glad (i det omfang de ikke er tilstræbte regionale skriftsprogsformer - og dermed bevidste afvigelser), til udtalemæssig distinkthed, fx "poleti" for politi (Pallesen 1999, Juul 2012) og "genetiv" for genitiv (Rathje 2019), eller til nyere lydudviklinger, fx "rat" for ret og "rosser" for russer. Det er let at finde eksempler på normkonflikter af type 2, især når det gælder konflikt mht. distinkthed. For at illustrere lidt mere indgående hvad det drejer sig om, giver vi i det følgende en række autentiske eksempler på stavefejl der kan formodes at have rod

5 I den forbindelse kan man også diskutere hvilken vægt der skal lægges på "korrekt" stavning som bedømmelsesparameter i uddannelsessystemet, og om alternative stavemåder også i uddannelsessystemet kan betragtes som en del af skribentens personlige "stemme" (se fx fagvejledningen for dansk på stx-niveau, Gymnasiekontoret 2020). 
i distinkthedsforskelle; jf. også Becker-Christensen (2021: 299-302).

Konsekvenser af schwa-assimilation og schwa-bortfald kan $\mathrm{fx}$ ses ved

- udeladelse af finalt $e$ efter et konsonantbogstav der repræsenterer en sonorant: "tak for de pæn ord", "Næsten på alle årstider møder man de sjov køretøjer",

- stavelsesreduktion, inklusive schwa-bortfald: "En frygtlig historie hunfor-tæller", "problemetersåatmineforældreer enligmeget søde", "Er jeg den enste der har fået en regning med deres nye ekstragebyr",

- reduceret præteritum -ede: "Så lavet jeg lige ny banerekord",

- reduceret -ere: "Vildbasserne havde i dag besøg af tre tysker".

Eksemplerne med -ede og -ere afspejler den almindelige, men jo i forhold til skriftens udgangspunkt lidt udistinkte udtale hvor to enslydende lyde reduceres til én: -ede [ợ $]>[ð]$, -ere $[\mathfrak{e r}] \rightarrow[\mathfrak{e}]$.

Konsonanttab forekommer i flere kontekster, $\mathrm{fx}$

- adverbielt $t$ på attributiv plads: "hel vildt", "vild god" (for helt vildt og vildt god),

- $\quad$ adjektivisk $t$ i prædikativ funktion: "Det er normal at være mere følsom psykisk efter en fødsel”,

- i konsonantklynger i øvrigt: "Jeg har altid drømt om, at opleve følelsen af at være vægløs [...] ja næsten flyve. Det kunne være super fedt!", "3,4 arbejsløs per ny medarbejder!!",

- $\quad$ r-tab i prætonisk position: "vudere" (for vurdere).

Når man som underviser skal identificere og forholde sig til normkonflikter som disse, er det, som det fremgår, nødvendigt at have et godt kendskab til udtalemæssig variation, ja, i nogle tilfælde nok ligefrem et særdeles godt kendskab til dansk udtale og udtalevariation. Afvigelser fra RO-normen kan være ganske forståelige hvis man er opmærksom på skribentens udtaleregister, hvorimod de kan fremstå som lydstridige hvis man holder dem op mod distinkte rigsmålsudtaler. Endvidere kan

6 Præcise kildeangivelser kan fås ved henvendelse til forfatterne. Se Brink m.fl. (1991: 15891619, 1631), Grønnum (2007: 173-187), Pharao (2010), Schachtenhaufen (2013) og Heegård Petersen m.fl. (2021: 127-146) for beskrivelser af almindelige spontantaleprocesser i dansk. 
stavemåder der afspejler at bøjningsendelser ikke altid udtales, føre til en fejlagtig opfattelse af at skribenten ikke behersker sprogets grammatiske regler.

\subsubsection{Udtalevariation og grammatik}

Det er vigtigt at være opmærksom på at i et udtaleperspektiv er stavefejlene der er nævnt i punkterne ovenfor, ikke udtryk for manglende grammatisk viden. Skribenter der laver sådanne fejl, kan fx sagtens skelne mellem verbers infinitiv og præsens når der ikke er lydligt sammenfald. At betragte fejlene som udtryk for manglende grammatisk viden vil derfor implicere at skribenten led af agrammatisme - eller var L2-lørner af dansk - og fx benyttede infinit supinum for finit præteritum til at betegne en fortidig begivenhed ("lavet" for lavede) og ikke beherskede almindelige kongruensregler for bestemthed ("den lukket $\mathrm{d} ø \mathrm{r}$ " for den lukkede dør) eller numeruskongruens ("tre tysker" for tre tyskere). Det er kun hvis man ikke kender til almindelig udtale af de her nævnte fejlstavede ord, at man kan blive forledt til at tro at skribenterne ikke kan dansk grammatik. Fejlformerne er jo gode gengivelser af en af de måder talesprogsgrammatikken kan komme til udtryk på. De er blot fejlformer fordi de gengiver ikke-distinkte udtaler. ${ }^{7}$

\subsubsection{Distinkthedsniveauer og udtaleundervisning}

Det forhold at ord kan have forskellige udtalemuligheder, og at retskrivningen ofte (omend ikke altid) stemmer bedst med en distinkt rigsmålsudtale, lægger op til at udtalen bliver et fokuspunkt i undervisningen. Man skal dog være opmærksom på at staveundervisning er noget ganske andet end udtaleundervisning. At opfordre sine elever til at tale distinkt rigsmål, $\mathrm{fx}$ ved at lade dem forstå at ordet glad skal udtales med blød d-lyd, at egentlig skal udtales med tre stavelser, eller at man skal udtale endelsen -ede tostavet, er ikke staveundervisning, men udtalenormering (Kristiansen 1990). Fremfor at rette på elevernes udtaler kan man opstille korrespondensregler med udgangspunkt i de-

7 Som allerede nævnt handler normkonflikter dog ikke nødvendigvis om udtalemæssige forhold. De kan fx også handle om variation i ords bøjningsmorfologi, jf. præteritumsformer som "holdte", "landte" hvor RO anfører holdt, landede. Konflikter af denne art går vi ikke nærmere ind på i denne artikel, se Hansen (1993) for yderligere eksempler. 
res egen udtale, $\mathrm{fx}$ at den regiolektale $\mathrm{j}$-lyd til sidst i glad staves med $d$.

Det er dog uundgåeligt at der vil være en vekselvirkning mellem udtalenormer og ortografiske normer. Eksempelvis kan tilegnelsen af stavemåder, $\mathrm{fx}$ políti og genítiv, virke tilbage på skribentens opfattelse af ordenes distinkte udtale, sådan at i-lyd i den midterste stavelse bliver en del af vedkommendes udtalerepertoire. Ligeledes kan en skribent der med udgangspunkt i dagligdags udtalenormer skriver "leo" for leve, i mødet med den etablerede stavemåde blive bevidst om den betydelige afstand der kan være mellem dagligdags udtaler og distinkte udtaler i dansk, og tilføje den distinkte udtaleform [le:və] til sit udtalerepertoire.

At distinkte udtaler som [le:va] hos mange sprogbrugere kun forekommer i meget tydelig eller højtidelig udtale, hvis de overhovedet bruges, betyder ikke nødvendigvis at der er tale om en rent skriftsproglig konstruktion. Viden om at et ord kan have forskellige distinkthedsniveauer, kan iagttages allerede i indskolingen, hvor nogle børn spontant kan bruge udtaler som ['np:və] og [ka'kæ:və] for Norge og kakao, hvor v-lyden ikke kan skyldes stavemåden (Schelde 2018, Brink 2021).

Der er en glidende overgang mellem distinkte udtaler som leve med v-lyd (en udtale der faktisk forekommer) og læseudtaler (også kaldet skriftnare udtaler), hvor der etableres en udtale som ellers ikke forekommer, men som stemmer med stavemåden. Ordene blive og give kan eksempelvis få læseudtalerne [bli:və], [gi:və] selv om deres distinkte udtaler ifølge Den Danske Ordbog (herefter DDO; ordnet.dk/ddo) er [bli:ə] ${ }^{8}$ og [gi:?] uden v-lyd. Læseudtaler kan i nogle tilfælde være en pædagogisk støtte (Elbro m.fl. 2012), men man skal som underviser gøre sig klart at man ikke kan slutte fra et ords stavemåde og til dets "korrekte" eller "egentlige" udtale, og at udgangspunktet for staveundervisning må være en form for distinkt, men ikke overdistinkt udtalt dansk som det tales i dag. Når en stavefejl svarer til den distinkte rigsmålsudtale - fx "blie" for blive, "tradve" for tredive - er der efter vores opfattelse ikke tale om normkonflikter, men om normhuller (jf. næste afsnit). Det samme gælder stavemåder der afspejler kortformer som er veletablerede også i distinkt udtale, fx "ku" for kunne, "ha" for have

8 Bemærk at DDO af hensyn til lydskriftens læsbarhed ikke gengiver schwa-assimilation - heller ikke i tilfælde som her, hvor schwa-assimileret udtale ['bli:i] er det almindelige selv i distinkt udtale (Brink m.fl. 1991). 
og "oss" for også (fx Brink \& Lund 1975: 479-480). Man kan gå ud fra at når sådanne distinkte kortformsudtaler er angivet i DDO, er de (for længst) etableret i dansk, og staveformen afspejler således ikke en konflikt med rigsmålsnormen.

\subsubsection{Normhuller}

Selv om man tager udgangspunkt i distinkte, konservative rigsmålsudtaler, er der overordentlig mange ord i dansk som kan være svære at stave. Vi nævnte i forrige afsnit blive og tredive som eksempler på ord der har stavemåder der ikke er fuldt forudsigelige ud fra udtalen. For at lære disse stavemåder har man brug for viden om de korrespondensregler der kan opstilles som bindeled mellem ordenes udtaler og deres normerede stavemåder. Korrespondensregler kan gælde specifikke ord ( $\mathrm{fx}$ at tredive er med $i$ og at blive er med $v$ ), eller de kan gælde på mere generelle niveauer ( $\mathrm{f} x$ at konsonanter ofte fordobles efter kort vokal, og at navne skrives med stort begyndelsesbogstav) eller på helt elementært niveau (at s-lyd oftest repræsenteres af bogstavet $s$ osv.). Når årsagen til en stavefejl er at skribenten mangler viden om korrespondensregler, men ellers behersker rigsmålsnormen, taler vi med Telemans terminologi om et normbul.

Begrebet normhul har stor relevans som årsag til stavefejl fordi der er så mange korrespondensregler at lære i dansk ortografi. Hvis man som lærer mistænker at en stavefejl skyldes et normhul, gælder det selvfølgelig om at indkredse hvad det mere præcist er for en korrespondensregel eleven ikke kender. Nedenfor i afsnit 3 giver vi et overblik over korrespondensregler i dansk ortografi.

\subsubsection{Normsammenbrud}

Stavefejl kan skyldes at skribenten mangler rutine i at følge korrespondensregler som vedkommende egentlig godt kender. Elever i indskolingen og på mellemtrinnet fortæller nogle gange at de faktisk godt ved at navne skal skrives med stort begyndelsesbogstav - de glemmer bare at gøre det. Og i udskolingen og endnu senere kan brugen af nutids-r være velkendt stof - som man blot ikke har overskud til at tænke på når man skriver (Schack \& Jervelund 2016, Rathje 2019, Holsting m.fl. 2021). Som betegnelse for denne type årsag til stavefejl kan man bruge Telemans term normsammenbrud. 
Betegnelsen sammenbrud kan virke lovlig dramatisk, men i tilfælde hvor begyndere og utrænede skribenter kæmper med at repræsentere ords lydstruktur, kan den være ganske rammende. Selv om begyndere faktisk kender alle bogstaverne og deres lyde, springer de ofte lyde over når der er tale om komplekse stavelser med flere konsonanter i træk, fx "ko" for klo (se nærmere om sådanne konsonantklyngefejl i Juul \& Sigurðsson 2005). Ligeledes kan lange ord give anledning til fejl, især når den samme eller en ensartet bogstavsekvens går igen i ordet, $\mathrm{fx}$ "autentitet" for autenticitet (jf. begrebet strukturparallellisme, Lund 1985; se også Juul \& Petersen 2017 om længdeeffekter). I disse tilfælde kan man tale om sammenbrud i den forstand at skriveprocessens krav overstiger elevens kognitive resurser.

Rene slåfejl og smuttere (som når tastaturet forskubber sig, og $o p$ bliver til "på”) kan også betragtes som eksempler på normsammenbrud. Igen er det ikke selve stavefærdigheden der mangler, men opmærksomhed og omhu i udførelsen. Det kan være fristende at bagatellisere denne slags fejl ud fra den betragtning at skribenten nok selv ville rette dem hvis vedkommende havde læst korrektur, og de omtales også mindre dramatisk som tilfaldige fejl (Hansen 1980) og som distraktionsfejl (Diderichsen 1968, Detlef m.fl. 1986). Men at tage hensyn til sin læser ved at læse korrektur er ikke noget man kan regne med at elever gør af sig selv - det kan tværtimod være nødvendigt at italesætte det hyppigt som en del af undervisning i stavning (Rathje 2019: 420). Man skal således ikke overse at staveudvikling ikke kun handler om at opnå en rent intellektuel forståelse af forholdet mellem tale og skrift, men også om at automatisere brugen af bestemte stavemønstre og at få overskud til at monitorere sin egen skriveproces.

\subsection{Fortolkning som proces}

Det kan være svært at sige hvornår det er kendskabet til en regel der mangler, og hvornår kendskabet er til stede, men blot ikke er konsolideret. Der er med andre ord ikke altid en skarp grænse mellem begreberne normsammenbrud og normhul. I det hele taget kan man, som vi tidligere har været inde på, sjældent være helt sikker på hvad der er årsag til en konkret stavefejl. Men vi har i dette afsnit lagt op til at man ikke desto mindre overvejer de principielle muligheder, og at man i den forbind- 
else er opmærksom på sprogets udtalemæssige variation. Begreberne normkonflikt, normhul og normsammenbrud er først og fremmest vigtige fordi de pædagogiske modsvar er helt forskellige. Normkonflikter kalder på øget opmærksomhed på sprognormer, normhuller kalder på øget viden om korrespondensregler, og normsammenbrud kalder på opøvelse af større rutine og korrekturlæsningsvaner. Distinktionen er derfor principielt vigtig for sprogpædagoger (Diderichsen 1968: 153).

Mange fejl kan fortolkes på flere måder, og det er vigtigt ikke kun at optælle fejl, men også at overveje skrivesituationen (har skribenten haft god tid og mulighed for ordbogsopslag?) og ordenes hyppighed. En skribent kan godt have lært at bruge dobbeltkonsonant i nogle enkelte hyppige ord ( $\mathrm{fx} i \underline{k k e}$, kaffe, drikke) sådan at et normhul (en mangelfuld tilegnelse af fordoblingsreglen) ikke opdages hvis man ikke også ser på mere sjældne ord. Fortolkningsarbejdet må i sagens natur være en løbende proces hvor man om muligt også inddrager udsagn fra skribenten selv. Når et mønster viser sig, begynder man ofte at kunne indkredse årsager med større sikkerhed fordi fejlene viser sig på tværs af ord.

\section{KORRESPONDENSREGLER}

Ovenfor udpegede vi normhuller som en væsentlig årsag til stavefejl, og vi definerede et normhul som et manglende kendskab til de korrespondensregler der forbinder det talte og skrevne sprog. I dette afsnit giver vi et overblik over de typer af korrespondensregler man skal kende for at blive en god staver på dansk. Vores typologi skelner mellem ubetingede og betingede regler og inddeler endvidere de betingede regler ud fra det sproglige niveau de knytter an til. Et overblik er vist i figur 2, og nogle eksempler på stavefejl der kan relateres til de forskellige typer af korrespondensregler, er vist i tabel 1.

Afsnittet her kommer kun ind på nogle udvalgte korrespondensregler i dansk. For detaljerede oversigter henviser vi til Becker-Christensen (2021, især s. 115-219) og til netstedet Bogstavlyd (bogstavlyd. ku.dk). Andre fremstillinger af forholdet mellem tale og skrift i dansk er blandt andet Aage Hansen (1967: 311ff.), Erik Hansen (1999), Jervelund (2007), Davidsen-Nielsen \& Herslund (2013), Mørch (2014) og Hauerberg Olsen (2018). De korrespondensregler vi omtaler, tager 
udgangspunkt i distinkte enkeltordsudtaler som anført i DDO, sådan som det også er tilfældet på netstedet Bogstavlyd. ${ }^{9}$

FIGUR 2. OVERSIGT OVER TYPER AF KORRESPONDENSREGLER

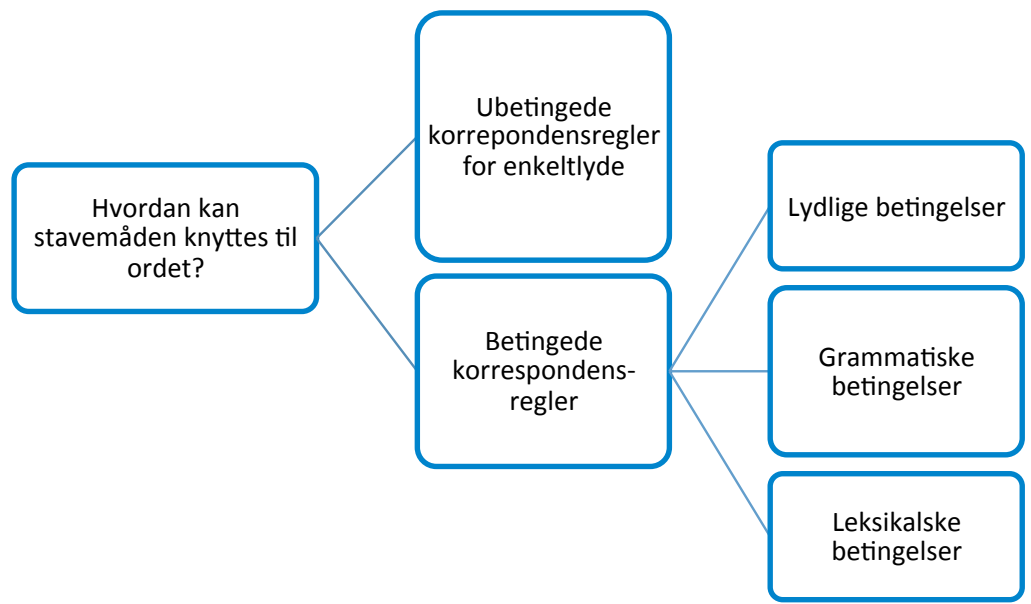

\subsection{Ubetingede korrespondensregler for enkeltlyde}

De ubetingede korrespondensregler for enkeltlyde udgør kernen i alfabetiske skriftsprog som dansk. De optager en væsentlig del af undervisningen $\mathrm{i}$ indskolingen (børnehaveklassen og 1 . klassetrin) hvor man fx lærer at s-lyd kan repræsenteres af en særlig grafisk slangeform, bogstavet $s$, mens i-lyd kan repræsenteres af en lodret streg med en prik over, bogstavet $i$. Udrustet med disse og en hel del flere korrespondensregler kan man allerede stave til is og si og andre lydrette ord - dvs. ord hvor hver lyd repræsenteres af sin standardstavemåde, $i$ for i-lyd, $s$ for s-lyd og så videre (om begrebet lydret, se Juul 2016). Når man taler om at

9 Becker-Christensen (2021) indskyder et fonologisk niveau imellem bogstav/grafem-niveauet og udtale/fon-niveauet idet han dels opstiller korrespondensregler der forbinder grafemer og fonemer, dels opstiller regler der forbinder fonemer og enkeltlyde (se fx Heegård Petersen m.fl. 2021, kap. 3 om begrebet fonem). Dette kan forenkle korrespondensreglerne betydeligt, se Becker-Christensen 2021: 103 for en illustration af dette. Vi har i denne artikel valgt at se bort fra fonemniveauet ud fra den betragtning at det ofte er diskutabelt hvordan lydsystemet skal analyseres, og om den samme fonemanalyse er gyldig for alle sprogbrugere, se fx diskussionen af a-lyde i Brink 2000 og Grønnum 2000. 


\begin{tabular}{|c|c|}
\hline Korrespondenstyper & Eksempler på stavefejl \\
\hline Ubetingede regler & $\begin{array}{l}\text { "cr" for ser (vokalen i ordet skal repræsenteres af et selvstændigt } \\
\text { bogstav) } \\
\text { "âl" for øl (det er } \emptyset \text { og ikke å der står for en ø-lyd) } \\
\text { "sal" for sjal (sj-lyd kan normalt ikke staves med } s \text { ) }\end{array}$ \\
\hline Lydlige betingelser & $\begin{array}{l}\text { "lile" for lille (manglende fordobling efter kort vokal) } \\
\text { "tark" for tak (ar for åben a-lyd bruges normalt kun hvis vokalen } \\
\text { er lang, jf. farve, eller ubetonet, jf. farvel) } \\
\text { "småk" for smuk (kort å-lyd staves normalt ikke med å) }\end{array}$ \\
\hline Grammatiske betingelser & $\begin{array}{l}\text { "Hun høre" for hører (manglende præsens-r) } \\
\text { "Hun kom løbene" for løbende (manglende markering af samtids } \\
\text { infinit) } \\
\text { "henrik" for Henrik (manglende markering af proprium) }\end{array}$ \\
\hline Leksikalske betingelser & $\begin{array}{l}\text { "hæst" for hest } \\
\text { "stord" for stor } \\
\text { "komune" for kommune } \\
\text { "kommite" for komite }\end{array}$ \\
\hline
\end{tabular}

alfabetiske skriftsprog bygger på et lydprincip, er det primært de ubetingede korrespondensregler der tænkes på.

At lære de ubetingede korrespondensregler kræver at man lærer at forbinde alfabetets bogstaver med deres mest almindelige lydlige korrespondenser. Men der skal mere til for at anvende dem i praksis, for det kræver at man bliver god til at opdele de ord man vil stave, i enkeltlyde, hvilket for mange børn er en ganske langstrakt læreproces og en særlig udfordring for ordblinde (Engmose 2019, Elbro 2021).

Nogle enkeltlyde er sværere at identificere og fastholde end andre. Eksempelvis kan cirka $85 \%$ af eleverne i starten af 1 . klasse stave vokalen korrekt i ord som mad og glad, mens kun omkring halvdelen gengiver den bløde d-lyd korrekt (se nærmere i Juul 2019 der rapporterer staveprøveresultater fra elever i 1.-6. klasse). For begynderen kan det desuden være en væsentlig forskel om der til den enkelte lyd svarer et enkelt bogstav, eller om der skal skrives flere bogstaver, fx $n g$ for ng-lyden i seng og sj for sj-lyden i sjov. Korrespondensregler af en-til-fleretypen er generelt sværere at lære.

Langt de fleste lyde har en stavemåde som er den klart hyppigste, hvilket typisk er den ubetingede, "lydrette", stavemåde ( $s$ for $s$-lyd, $i$ for i-lyd osv.; Mørch 2014 og netstedet Bogstavlyd). Det er naturligvis 
den stavemåde man har størst glæde af at lære. Som tidligere nævnt skal man dog være opmærksom på at adgang til ordenes distinkte udtaler ikke kan tages for givet. Ordet leve er fx lydret hvis man tager udgangspunkt i den distinkte rigsmålsudtale [le:və], men for den der altid udtaler det [le: $]$, dvs. omtrent som Leo, kan det være overraskende at ordet skal staves med $v$. Kendskab til distinkte rigsmålsudtaler vil således kunne øge de ubetingede korrespondensers anvendelighed.

\subsection{Betingede korrespondensregler}

For næsten alle danske lyde findes der en længere række af mulige korrespondenser, sådan at man sjældent kan vide med sikkerhed om den mest anvendte stavemåde er den korrekte i et givet ord. En bogstavlyd-søgning på lang i-lyd [i:] viser fx ti forskellige mulige stavemåder

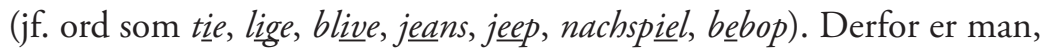
hvis man vil følge RO-normen, nødt til ikke blot at lære de ubetingede korrespondensregler (de lydrette stavemåder), men også en række betingede korrespondensregler (jf. figur 2).

Hvor de ubetingede regler gælder for enkeltlyde, knytter betingelserne an til andre sproglige niveauer. I sidste instans kan en stavemåde altid knyttes til det enkelte ord (en leksikalsk betingelse). Men ofte kan man opstille betingelser der gælder for flere ord med fælles lydlige eller grammatiske karaktertræk. I de følgende afsnit beskriver vi hver gruppe af betingede regler - lydlige, grammatiske og leksikalske (se også Becker-Christensen 2021: 30-32).

Betingede staveregler giver anledning til to slags stavefejl. Dels kan betingede stavemåder blive erstattet af ubetingede stavemåder - som når lige staves "lie" uden det stumme g. Dels kan betingede stavemåder blive brugt hvor de ikke hører hjemme - som når tie staves "tige". Stavefejl af den første type kan kaldes regulariserende fordi en uregelmæssighed "rettes ud", det stumme g undgås. Den sidste type kan kaldes overgeneraliserende fordi en stavemåde ikke kun anvendes hvor betingelsen gælder, men mere generelt; det stumme g indføjes i analogi med ord af lignende lydlig struktur der har et stumt g. Overgeneraliserende stavefejl kan være et tegn på at en betinget stavemåde er ved at blive lært - blot er selve betingelsen endnu ikke på plads. 


\subsubsection{Lydlige betingelser}

At en stavemåde knyttes til en lydlig betingelse, ses når en korrespondensregel gælder for en lyd i en bestemt lydlig sammenhæng. Eksempelvis staves en d-lyd oftest med $t$ hvis d-lyden står til sidst i et ord, som i hat, nat, telt, Kurt. Og om g-lyde gælder det at de staves med $k$ hvis de står lige efter en s-lyd i samme stavelse, som i sko, skik, vask, dans $\underline{k}$. Man kan her tale om at ortografien er styret af et udvidet lydprincip hvor korrespondensreglerne gælder lydfølger frem for enkeltlyde (Elbro 2014 bruger betegnelsen "Lydprincippet 2"). ${ }^{10}$

Mange elever lærer de to nævnte lydligt betingede stavemåder allerede i indskolingen, mens andre lydligt betingede stavemåder først tilegnes på mellemtrinnet eller endnu senere. Således kommer reglen om at intervokaliske konsonanter skrives dobbelt efter en kort trykstærk vokal - jf. forskellen på basse og base - typisk først på plads i 3.-5. klasse. Det samme gælder reglen om at å-lyd oftest staves med $u$ hvis der er tale om en kort vokal, hvorimod lang å-lyd staves med a (Juul 2019).

\subsubsection{Grammatiske betingelser}

En helt anden type betingelser ses når en korrespondensregel gælder for ord med bestemte morfologiske slægtskabsforhold eller en bestemt syntaktisk funktion, som vi her vil omtale samlet som grammatiske betingelser. Den nok mest velkendte regel af denne type er reglen om verbers endelser i præsens vs. infinitiv. I de fleste danske verber kan man følge de ubetingede korrespondensregler, $\mathrm{fx}[\mathrm{r}]=e r$ i nutidsformen foler, mens $[\partial]=e$ i infinitiven fole. Når stammen i et verbum ender på $-r$, udtales begge endelser imidlertid med åbent schwa [ $\mathrm{e}]$. Her kan kun en grammatisk analyse afgøre om den korrekte stavemåde af eksempelvis verbet [fø:e] er fører eller føre, hvilket er en udfordring for mange selv i grundskolens ældste klasser, på ungdomsuddannelser og endda på universitetsniveau (Juul \& Elbro 2004, Schack \& Jervelund 2016, Møller \& Juul 2017, Rathje 2019, Holsting m.fl. 2021). Korrespondensreglens betingelse refererer her til verbernes syntaktiske funktion

10 Brugen af $s k$ frem for $s g$ understøttes desuden af de rent grafotaktiske forhold - dvs. bogstavernes kombinationsmuligheder uanset deres udtale (Treiman \& Kessler 2021). Forbindelsen $s g$ forekommer fx kun helt undtagelsesvist i samme stavelse i danske ord (sgu, sgisme), mens sk er en hyppigt anvendt bogstavkombination. 
og tilstedeværelsen af bestemte bøjningsendelser. ${ }^{11}$

Grammatiske betingelser kan også gælde rodmorfemers stavemåde. Ud fra udtalen kunne substantivet blast udmærket staves med $e$ ligesom vest. Men stavemåden med $\mathfrak{a}$ understøttes af at ordet blast har samme rodmorfem som verbet blxase. Ligeledes understøttes det stumme d i mord af de udtalte $d$ er i beslægtede ord som morder og myrde. Der er overordentlig mange af den slags eksempler på at danske ords stavemåder er bestemt af de morfemer der indgår i ordet, og antallet af normhulsfejl kan således nedbringes betydeligt hvis man som skribent er opmærksom på ords morfologiske slægtskaber.

\subsubsection{Leksikalske betingelser}

I mange tilfælde er man nødt til at gøre det specifikke ord til betingelsen for en korrespondensregel fordi den ikke kan knyttes til lydlige eller grammatiske betingelser. Der er tale om en leksikalsk (ordspecifik) betingelse når man må lære at der skal stumt $\mathrm{d}$ i stald, men ikke i smal, og at vest er med $e$, hvorimod gast er med $a$. Man kan her tale om at ortografien er styret af et traditionsprincip (et ords stavemåde ændres ikke når den først er etableret), og i nogle tilfælde et etymologisk eller internationalt princip (ord staves i overensstemmelse med deres oprindelse; Jervelund 2007, Davidsen-Nielsen \& Herslund 2013, Becker-Christensen 2021: 62-65).

Leksikalske betingelser kan være vanskelige selv for erfarne skribenter. Det gælder ikke mindst de mange tilfælde hvor en stavemåde med dobbeltkonsonant må knyttes til det enkelte ord, nemlig når fordoblingen følger efter en tryksvag vokal. Her har vi nogle gange fordobling som i massere, andre gange enkeltkonsonant som i basere (sammenlign også ballade vs. balance; skelettere vs. trompetere; parallelisere vs. karamellisere). Sådanne leksikalt bestemte konsonantfordoblinger er væsentligt sværere end de ovennævnt lydligt bestemte fordoblinger (se Møller $\&$ Juul 2017 vedrørende beherskelsen af de to slags fordoblingsregler blandt elever i 6.-8. klasse).

Ordspecifikke stavemåder kan være særlig drilagtige når ordet (eller en

11 Nogle fremstillinger taler i denne forbindelse om et tegnkonstansprincip (Hansen 1999, Jervelund 2007) eller om morfogrammatisk funktion (Davidsen-Nielsen \& Herslund 2013). 
del af det) deler udtale med et ord med en anden stavemåde, men med en beslægtet betydning. Det er ikke svært at adskille jul og hjul - men er forsteder beslægtet med sted eller med stad (jf. stavefejlen "forsteder"; Hansen 1999)? Er uvist beslægtet med vished eller med viden (jf. stavefejlen "uvidst")? Og er udtrykket at vonne sig til noget beslægtet med en vane, med at vende sig om eller med at blive venner med nogen? Den støtte man generelt kan finde i morfologiske slægtskaber, bliver her til en forhindring. ${ }^{12}$

Leksikalske betingelser knytter sig, som det er fremgået, til enkeltord, men de kan også være mere generelle, nemlig når stavemåder kan knyttes til et etymologisk defineret lag i ordforrådet. Eksempelvis finder vi især stavemåden sch i ord der er lånt fra tysk (schafer, schwung, schnauzer), mens sh hører til i engelske lån (shoppe, shampoo, showroom) og ch i franske (chablis, champignon, champagne). Et andet eksempel er stavemåden $p$ der kun findes i ord af græsk oprindelse ( $p$ syke, pseudonym, psoriasis). Disse signaler om ords oprindelse giver ortografien kulturhistorisk kolorit - men for den der skal lære at stave, er de en hurdle. Leksikalsk betingede korrespondensregler giver i det hele taget anledning til mange normhulsfejl, dels fordi der er så mange af dem, dels fordi de hver især kun gælder for et enkelt eller nogle få ord.

\section{ER DET BLEVET SVÆRERE AT STAVE?}

De korrespondenser vi omtalte i forrige afsnit, bygger som nævnt på distinkte rigsmålsudtaler sådan som de fx fremgår af DDO. Men udtalenormer varierer og ændrer sig, og som staveunderviser er det som omtalt ovenfor nødvendigt at kende til denne variation, sådan at man kan opdage det når stavefejl har rod i en normkonflikt, og sådan at man kan undervise i korrespondensregler med udgangspunkt i moderne dansk udtale. Derfor ser vi i dette afsnit på hvordan forholdet mellem udtaler og stavemåder har ændret sig i de seneste generationer. Vi ser især på udtaleudviklinger der ikke fremgår af oplysningerne i DDO, og som

12 På den anden side kan man også (især fra en læsers synsvinkel) se det som nyttigt at homofone ordpar har forskellige stavemåder, sådan at det tydeliggøres hvilken ordbetydning der er den relevante (jf. det såkaldt distinktive princip; Jervelund 2007). Herimod kan man dog så indvende at talesprogets homofoner kun sjældent fører til misforståelser, og at det ville være endnu mere nyttigt at prioritere et padagogisk princip og gøre alle stavemåder så lydrette som muligt og dermed lettere at lære. 


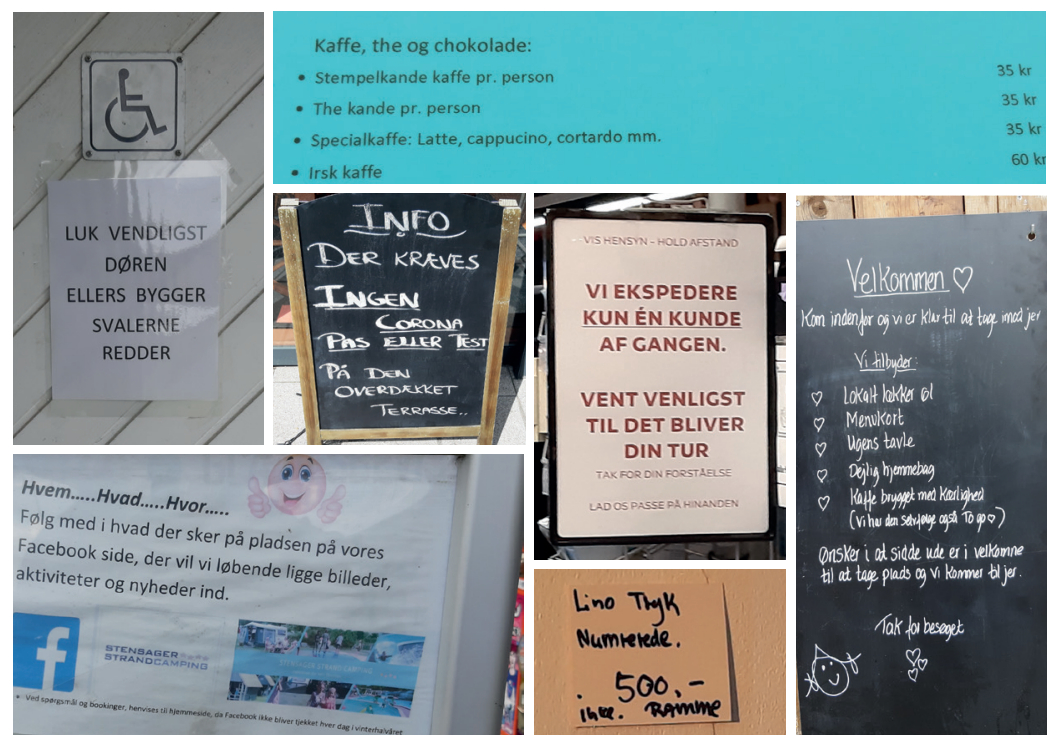

FIGUR 4. EKSEMPLER PA NORMKONFLIKTER OG NORMHULLER I DANSK SKILTESTAVNING. Normkonflikter ses ved de staveformer der viser reduceret udtale ("den overdækket terrasse", "selvfølge" selvfolgelig (jf. almindelig reduceret, tryksvag udtale [səføll a]), "numrerede" for nummererede), ikke-standard genus ("lækker øl", "dejlig hjemmebag") og ikke-standard udtale af lagge ("ligge billeder op"). Normhuller ses ved "cortardo" for cortado, "ekspedere" for ekspederer, "af" for ad og "vendligst" for venligst, hvor stavefejlene repræsenterer samme udtale som de korrekte former.

fører til nye flertydigheder i relationen mellem udtale og retskrivning. Spørgsmålet vi stiller, er om det er blevet sværere at stave. Afsnittet er tænkt som en opdatering af en artikel af Jørn Lund (1978) der stillede det samme spørgsmål og stadig læses af mange danskstuderende.

De udviklinger vi vil omtale, har vi opdelt i fire kategorier (se figur 5): ændringer mht. udtaledistinkthed, ændringer mht. vokallængde, ændringer som følge af r-påvirkning af vokaler og en restkategori med øvrige ændringer. Formålet er at give overblik over de udviklinger der især er interessante for staveundervisere og i forhold til eventuelle revisioner af retskrivning. Grundigere beskrivelser af udtaleudviklinger i moderne dansk kan man finde i Grønnum (2007), Brink \& Lund (2019), Heegård Petersen m.fl. (2021: kap. 12). Vores gennemgang opsummeres i tabel 3 i afsnit 4.2.7. 


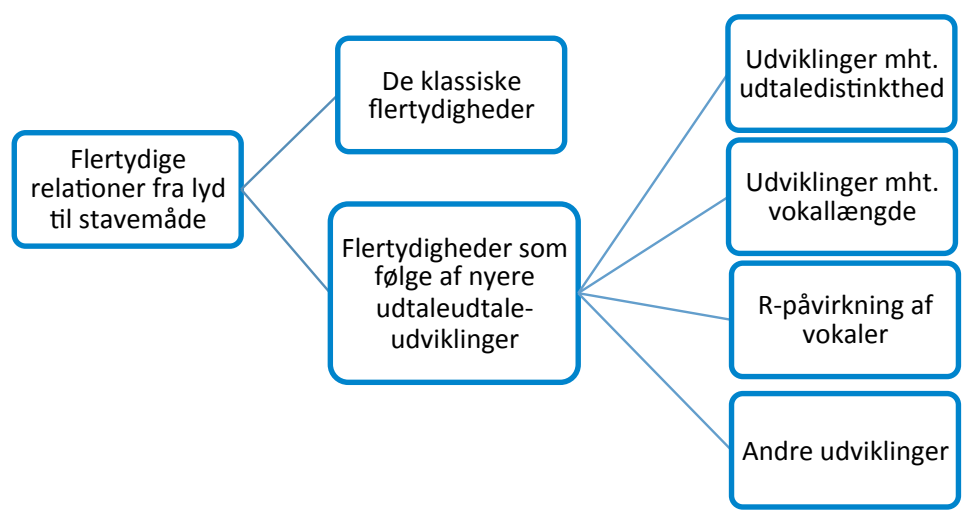

FIGUR 5. UDTALEUDVIKLINGER OG STAVNING

\subsection{Klassiske flertydigheder}

Inden vi ser nærmere på udtaleudviklingerne i de seneste generationer og de flertydigheder de har ført til, må vi fremhæve at flertydige relationer ikke er et nyt fænomen. Tabel 2 giver nogle eksempler på "klassiske" flertydigheder i dansk.

Mange af disse flertydigheder går meget langt tilbage i sproghistorien. Af oversigter i Dansk Sproghistorie (Frederiksen 2019) og i Becker-Christensen (2021: 53-58) fremgår det at der allerede i 1200-tallet var variation i hvordan skriverne repræsenterede de forskellige lyde i dansk. Eksempelvis kan kort $x$-lyd allerede her ses skrevet nogle gange med $e$, andre gange med $a$. Endvidere er der udtaleudviklinger som fandt sted for flere hundrede år tilbage, som stadig ikke afspejles af retskrivningen. Det gælder blandt andet de udviklinger der førte til at h- og d-lyd forsvandt fra udtalen i visse sammenhænge mens det stumme h og det stumme d er bibeholdt i skriften (Gregersen 1981, Frederiksen 2019: 52). Lidt spøgende sagt er ortografisk uregelmæssighed altså nærmest en del af den danske kulturarv. Andre flertydigheder er kommet til tættere på moderne tid. Eksempelvis udviklede den bløde g-lyd sig i ord som hige, søge, valge, følge i løbet af det 19. århundrede til en $\mathrm{j}$-lyd, hvis stavemåde dermed blev flertydig ( $j$ eller $g$ ).

Den historiske baggrund for flertydighederne er, som det fremgår, ofte udtaleudviklinger. I andre tilfælde skyldes de såkaldt falske restitutioner (en form for overgeneralisering), som når spilde og kvinde staves 


\begin{tabular}{|c|c|}
\hline Flertydighed & Eksempel \\
\hline stumt $h$ før $j$ og $v$ & 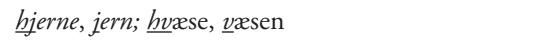 \\
\hline stumt $d$ efter $l \log n$ & kilde, spilde, lille, spille; binde, kvinde; finne, skinne \\
\hline enkelt- eller dobbeltkonsonant ml. vokaler & bas e, basse; las e, lasse \\
\hline udtalesammenfald af endelser & -rel-rer; -enel-ende \\
\hline$x$-lyd med $e$ eller $a$ & vest, gexst \\
\hline$\varnothing$-lyd med $y$ eller $\emptyset$ & kㅁlle, skylle \\
\hline j-lyd med $j$ eller $g$ & alge, balje; log, loj \\
\hline blød v-lyd med $v$ eller $g$ & krage, krave \\
\hline sj-lyd med $s j / s h / s c h / c h$ & sjette, sherry, schafer, chef \\
\hline b-lyd med $b / p$ hhv. $b b / p p$ & $\underline{b} a k$, spak; råbe, rype; ribber, ripper \\
\hline g-lyd med $k / g$ hhv. $k k / g g$ & gud, skud; fortolker, Holger; bakke, begge \\
\hline d-lyd med $d|t| d t \mid t t$ & $\underline{d y r}$ styr; bolt, bold, koldt; godte, rottee \\
\hline
\end{tabular}

med stumme d'er der ikke skyldes at ordene tidligere har været udtalt med d-lyd. Stavemåderne med stumme d'er er her opstået som en slags stavefejl fordi man har stavet i analogi med andre ord hvor en tidligere d-lyd var forsvundet, fx kilde og binde. I atter andre tilfælde skyldes flertydigheder at ord er lånt fra fremmedsprog uden at stavemåden er tilpasset til dansk, sådan som det ses i mange af ordene med sj-lyd i tabel 2.

\subsection{Udviklinger mht. distinkthed}

Der vil altid være distinkthedsvariation i udtalen af et sprog (Heegård Petersen m.fl. 2021: kap. 11), men normen for distinkt udtale kan hos grupper af sprogbrugere ændre sig sådan at udgangspunktet for staveprocessen bliver et andet. Dermed kan der opstå nye tilfælde af normkonflikter og normhuller (jf. afsnit 2 ovenfor). I det følgende ser vi på en række mulige udviklinger mht. distinkthed, men med opfordring til at der anstilles nærmere diakrone undersøgelser på dette område, som desværre ikke er særlig godt undersøgt. 


\subsubsection{Svakkede r-lyde}

Jørn Lund skriver at "[a]f nyere, men ikke ny dato er det forhold, at der svarende til skriftens skelnen mellem -er og -re efter vokal ikke altid hos yngre er nogen udtalemæssig distinktion” (1978: 181). Lund nævner ord som ture og tuer, kure og kuer som eksempler på stavemåder der ikke længere kan holdes adskilt ud fra udtalen. I dag er udtaler uden konsonantisk r-lyd blevet den distinkte udtalenorm ifølge DDO, der anfører ['tu:e] og ['ku:e] for ture og kure. Det betyder at man ikke længere kan stave ud fra simple, ubetingede korrespondensregler som da de gamle distinkte udtaler var fremherskende - ['tu:ье ' ku:ье] og så videre. I stedet må man lære korrespondensregler med grammatiske og leksikalske betingelser for at afgøre om ordene skal ende på er, (r)re eller -(r) rer. Som det fremgår, kan man dog stadig være sikker på at der skal være et $r$ i sidste stavelse af de nævnte ord.

Svækkelsen af r-lyd mellem vokaler er ikke en fuldt gennemført proces. Et tegn på dette er at DDO, som er baseret på Brink m.fl. (1991), angiver udtalen af forum med r-lyd ['fо:ьот], mens ordet durum er uden ['du:om]. Efter tryksvag vokal er der ligeledes en stærk tendens til r-tab, jf. ord som vurdere, servere, kiropraktor (Jørn Lunds eksempler). Her er det dog stadig udtaler med bevaret r-lyd der fremgår af DDO. De udtaler der anføres i DDO, viser heller ikke tendensen til bortfald af r-lyd mellem konsonant og tryksvag vokal, som giver sammenfald af klatter og klatre, klammer og klamre, baller og baldre, gnister og gnistre, fatter og fatre. Jørn Lund nævner sådanne sammenfald, men det er vores indtryk at udviklingen er fortsat, og at mange unge i dag kun skelner ordene i meget distinkt udtale eller som læseudtaler. Dette understøttes af at mange elever udelader $r$ 'et når de staver ord som klatre og klamre (Juul 2019). Med sammenfald af ord som klatter og klatre bliver der brug for at knytte stavemåderne til morfologiske betingelser - fx at klatter enten er flertal af klat eller nutid af klatte og derfor skal ende på -er, mens det åbne schwa [e] til sidst i infinitiven klatre må skyldes påvirkning fra en r-lyd, da ordet ellers burde have almindeligt schwa [ə] som i klatte.

De nævnte tendenser til bortfald af r-lyd kan ikke blot føre til udeladelser af bogstavet $r$ i de berørte lydlige sammenhænge, men også til overgeneraliseringsfejl hvor der fejlagtigt indsættes et $r$. Fruer kan blive 
til "frurer" (jf. furer), duo til "duro" (jf. navnet Panduro), biograf til "birograf" (jf. kiropraktor) osv.

\subsubsection{Schwa-tab og schwa-assimilation}

En meget udbredt distinkthedsvariation i dansk er at endelses-e'et, schwa [ə], kan tabes, som når kaffe udtales enstavet som et rim på paf. Schwa kan også assimileres til stemte nabolyde, der så bliver stavelsesbærende. Denne assimilation er så godt som gennemført i ord som cykel, vissen ['sygl 'vesn] hvor udtaler med schwa ['sygəl 'vesən] for de fleste sprogbrugere virker overtydelige (Brink m.fl. 1991: 1573-1575). ${ }^{13}$ De schwa-assimilerede endelser kan hos begyndere føre til stavefejl hvor endelses-e'et er udeladt ("cykl", "visn"), men hvis man har dansk som modersmål, vil man normalt ikke være i tvivl om at ord med stavelsesbærende sonoranter er flerstavede (Schachtenhaufen 2011), og man skal så blot lære den korrespondensregel at stavelsesbærende l-lyd og n-lyd staves henholdsvis -el og -en.

I moderne dansk er tendensen til schwa-assimilation imidlertid efter vores indtryk blevet stærkere, sådan at schwa-assimilation nu også ofte høres i ord som cykle og visne, i hvert fald i mindre distinkt udtale, hvilket giver udtalesammenfald af cykel-cykle og vissen-visne. Det betyder at staveundervisere med fordel kan pege på grammatiske betingelser, $\mathrm{fx}$ at cykle og visne er infinitiver og derfor skal ende på -e.

Grammatiske betingelser bliver også nødvendige når schwa assimileres til en blød d-lyd. Det giver udtalesammenfald af gåde og gået, ride og riget, sådan at identifikation af bøjningsendelsen i gået, riget bliver afgørende når ordenes stavemåde skal læres.

I forhold til stavefejl kan man foruden udeladelser af $e$ (fx "ungdomlige" for ungdommelige; Schack \& Jervelund 2016: 93) se overgeneralisationer der tydeligvis har rod i schwa-tab og schwa-assimilationer. Det gælder fx når spejlag og lapning bliver til "spejleæg" og "lappening" (eksemplerne er observeret henholdsvis på en grillbar og hos en cykelsmed; se også Schachtenhaufen 2011 og eksemplerne nævnt i afsnit 2.2.3).

\subsubsection{Andre bortfald og assimilationer}

13 Når DDO anfører udtaler med schwa i disse ord, skyldes det et redaktionelt valg idet man undgår diakritiske tegn for dermed at gøre lydskriften lettere at læse. 
I sin omtale af den nu forsvundne bløde g-lyd noterer Jørn Lund at udviklingen til j-lyd hos børn ofte har udviklet sig videre, "således at lyden helt kan forsvinde" (Lund 1978: 183). Denne udvikling er nu yderligere fremskredet og fremgår i nogle tilfælde af udtaleoplysningerne i DDO, der fx har dag [dæ:?]. Bortfald af j-lyd giver sammenfald af ord som magle, maile, male, af $s ø g$, sø og af øger, ører med den konsekvens at stavemåderne med $g$ må knyttes til de enkelte ord eller om muligt til morfologiske ordfamilier (fx søge-søgt, smage-smagt).

Ovenfor nævnte vi at endelsen -et udtales som et stavelsesbærende blødt d. Når stammen i et ord ender på j-lyd eller blød v-lyd, assimileres disse stammefinale lyde ofte til den bløde d-lyd, sådan at der bliver udtalesammenfald af øjet, odde, af braget, brede og af revet, redde/reddet. Jørn Lund stiller det uforglemmelige spørgsmål Har du redde dig i odde? i sin behandling af disse sammenfald. De nævnte udtalesammenfald kan i dag iagttages også når rigsmålstalende voksne taler i et distinkt leje - og også her bliver det derfor vigtigt for tilegnelsen af stavemåder at inddrage morfologiske forhold - $\mathrm{fx}$ at $ø j e t$ er bestemt form af øje (med j-lyd), og at revet er supinum af rive (med blød v-lyd i distinkt udtale).

En nyere lydudvikling (i hvert fald nævnes den ikke af Jørn Lund) er at vokaler kan blive rundede når de står som nabo til labiale konsonantlyde, fx sådan at fem udtales [fœem?] som rim på søm, og biograf udtales med y-lyd [by:о' gва:?f]. Der vil derfor ikke være noget overraskende i stavefejl som "føm" og "byograf", men vi er dog ikke stødt på empiriske belæg. I tilfældet fem kan dette skyldes at tilegnelsen af stavemåden støttes af ordets hyppighed.

\subsection{Udviklinger mht. vokallangde}

Slår man ordparrene vade, vadde og bure, burre op i DDO, finder man at de i de anførte udtaler adskiller sig med hensyn til vokalens længde:

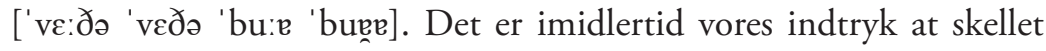
mellem lang og kort vokal i dag er forsvundet hos langt de fleste rigsmålstalende i ord som de nævnte, dvs. før blød d-lyd og før blød r-lyd, dvs.[ำ] henholdsvis 'åbent schwa' []. Olander (2019) mener, efter vores opfattelse korrekt, at det er udtaler med lang vokal der er blevet næsten enerådende i ord som de nævnte, men i nogle beskrivelser tales 
der tværtimod om forkortelse (Brink m.fl. 1991: 1576, 2019: 205-206, Grønnum 2007: 166-167). Uanset hvad er konsekvensen af udtalesammenfaldene at brugen af $d d$ og $r r$ ikke længere er forudsigelig ud fra udtalen. Ord med $d d$ og $r r$ kræver derfor at man lærer leksikalsk betingede korrespondensregler (Juul 2005), og staveundervisere der vil illustrere den lydbetingede fordoblingsregel, bør gå uden om ordpar som vade-vadde, bure-burre som i dag er homofone.

Også i ord med j-lyd mellem to vokaler kan der iagttages forlængelse. Det gælder eksempelvis ordene veje, pege, hvor de distinkte udtaler ['vaı̃ə 'paı̃ə] kan blive til ['va:I 'pa:I]. Her er der for det første sket det at j-lyden er schwa-assimileret og blevet til den tryksvage i-agtige vokal [I], hvilket derefter giver forlængelse af vokalen i første stavelse. En generel regel i moderne dansk er nemlig at korte vokaler forlænges når de står umiddelbart før en anden vokal i samme ord (Olander 2019). En konsekvens af forlængelse før j-lyd er at veje og varig kan falde sammen i udtalen ['va:I], sådan at det kræver kendskab til grammatiske betingelser at stave ordene korrekt (at veje er flertal af vej, mens varig med samme udtale er et adjektiv afledt af verbet vare).

En tilsvarende forlængelse er blevet almindelig før stavelsesbærende blødt d (som fonetisk set er en vokallyd), sådan at peget falder sammen med parret (vb.), begge med udtalen ['pa:ð̋]. Allerede Jørn Lund (1978) beskrev forlængelser som de nævnte, og vores (ikke empirisk belagte) vurdering er at forlængelserne i dag er nær ved at være fuldt gennemført - med en lang række udtalesammenfald til følge. Foruden de allerede nævnte fx nejet-narret, eget-ejet-arret, barre-bare, dier-diger-dirre, hare-herre, redde-rede, hedde-hede og gedder-geder, der nu alle kræver kendskab til leksikalske og/eller grammatiske betingelser hvis ordene skal staves korrekt.

En anden række sammenfald skyldes at lange vokaler med stød forkortes før blød d-lyd, sådan at verbet rider med den oprindelige udtale [' 'ві:?ðъ] falder sammen med substantivet ridder idet begge nu udtales [' 'віð’ $\mathrm{k}]$. Denne udvikling fører til usikkerhed om brugen af dobbeltkonsonanten $d d$, jf. stavefejl som "fodder" for foder og "puder" for pudder. Tilsvarende forkortes lange stødvokaler før blød v-lyd, sådan at $\mathrm{fx}$ sorg med den oprindelige udtale [sp:? $\mathrm{u}$ ] falder sammen med sov, begge ord nu med udtalen [spợ?]. 


\subsection{R-påvirkning af vokaler}

Naboskab til en r-lyd har ført til at en række vokaler har fået en mere åben udtale med stavemæssige flertydigheder til følge. Disse r-påvirkninger har ramt forskellige vokaler til forskellig tid. Nogle udviklinger er stadig i gang, mens andre er fuldt gennemført (Brink \& Lund 1975: 106-170, Grønnum 2007: 167-168).

En fuldt gennemført udvikling er at oprindelig lang e-lyd efter r-lyd er åbnet og faldet sammen med $x$-lyd, sådan at tre-tra og reb-rab, henholdsvis har fået samme udtale. Dette fremgår af DDO, som dog anfører ordene med en noget konservativ $æ$-lyd [tкв:? в:?b], hvor langt de fleste rigsmålstalende i dag efter vores indtryk har a-lyd, dvs. en yderligere åbning til [нъæ:? вæ:?b]. Man skal derfor ikke blive overrasket hvis begyndere bruger stavemåderne "tra" og "rab".

Hvad angår oprindelig kort $x$-lyd, er denne vokal i de fleste sammenhænge åbnet så meget at der er blevet sammenfald mellem brat og brat [bваd], rest og rast [ваsd] hos det store flertal af sprogbrugerne (Brink m.fl. 1991: 1584). Jørn Lund skriver om disse sammenfald (jf. også eksempler som ret-rat, skramme-skramme) at de findes hos "mange flere end for blot 25 år siden, hvor det især var børn af de lavere lag i København, der havde problemer med stavningen af sådanne ord" (1978: 180). Det skal bemærkes at før velær lukkelyd er r-påvirkningen i moderne sprog ledsaget af en diftongering, sådan at der fortsat er udtaleforskel på frakke ['fва丿⿱一兀)ə] og frakke ['f́аgə]. Til gengæld har denne udvikling så givet sammenfald af fx strakke og strejke, begge med udtalen ['sdвaigə].

I stilling før åbent schwa [e] (som historisk er resultatet af r-lyd + schwa), er lang $x$-lyd åbnet og faldet sammen med lang a-lyd, sådan at vi har fäet udtalesammenfald af are og aer ['æ:e], kare og kager ['kæ: e], svarere og svagere ['svæ:ę] (Brink m.fl. 1991: 1584). Heller ikke denne udvikling fremgår af DDO selv om den efter vores vurdering er fuldt gennemført hos det store flertal af rigsmålstalende.

En udvikling der til gengæld fremgår af DDO, er åbningen af kort e- og $x$-lyd før halvvokalisk r-lyd, der giver a-lyd i ord som smerte, erlig ['smær্də 'æenli]. Hvis man vurderer stavefejlen "smarte" for smerte lyd for lyd, er den således fuldt forståelig, og den forekommer faktisk hos begyndere. Udtaleudviklingen er for øvrigt gået videre i de seneste par 
generationer, sådan at [æe $]$ hos mange er blevet til en lang a-lyd, [æ:] eller [a:], hvilket giver udtalesammenfald af fx arlig og Ali ['æ:li], harge og have ['hæ: ]. Bemærk at bogstavnavnet $r$, der jo netop udtales [ææ], berøres af denne udvikling, sådan at $S R P$ (en forkortelse for gymnasieskolens studieretningsprojekt) kan få samme udtale som SAP.

For de høje vokaler i-, y- og u-lyd har der tidligere været r-påvirkning før r-lyd, sådan at kirke, dyrke, skurke har været udtalt med e-, ø- og o-lyd. Her er udviklingen imidlertid gået tilbage, sådan at ordene i dag udtales uden r-påvirkning og dermed er blevet mere lydrette. Efter r-lyd er der observeret en tendens til åbning af i-lyd, sådan at gris bliver et rim på fes og ikke på fis (Schachtenhaufen 2009). Denne udvikling er så vidt vi kan vurdere, kun i sin vorden - men det er formentlig kun et spørgsmål om tid før vi ser begynderstavefejl som "gres" for gris. En anden nyere r-påvirkning der kan føre til stavefejl, er tilbagetrækning af vokalen i ord som grøn, brønd, så de kommer til at rime på hånd (Grønnum 2007, kap. 12).

Langt mere fremskreden er r-påvirkningen efter $r$ når det gælder $\mathrm{u}$-lyd, som giver sammenfald af fx rude og rode ['во:ð], gru og gro [gво:?, krus og kros [kво:'s]. De nævnte eksempler er lånt fra Jørn

Lund, som vurderer at udviklingen endnu ikke er fuldt gennemført (i 1978). Her godt 40 år senere er det efter vores vurdering nok et flertal af sprogbrugere der har gennemført udviklingen (vi bygger blandt andet på ålige forespørgsler blandt studerende), men det er stadig ikke usædvanligt at høre rude, gru, krus udtalt med u-lyd, som også fortsat er de udtaler der anføres i DDO. Udviklingen kan, hos dem der har gennemført den, føre til stavefejl som "rode" for rude - og overgeneraliserende (o-lyd stavet med $u$ ) "rude" for rode.

\subsection{Andre udviklinger}

Ud over de udviklinger vi har nævnt ovenfor, er der yderligere en række udviklinger som dog ikke altid er væsentlige for staveundervisere. Visse vokaler har i betydelig grad ændret kvalitet, hvilket blandt andet fremgår af akustiske målinger af vokaludtaler i Danmarks Radios radioaviser fra forskellige årtier (Thøgersen 2012). Mest markant har den lange a-lyd i fx vase fået en kvalitet der ligger tæt på æ-lyden i hvose. Men så 
længe selve vokalsystemet er det samme, dvs. så længe a- og $x$-lydene i vase vs. hvase er klart forskellige, indebærer dette ikke nogen vanskelighed i stavning. Derimod har andre akustiske målinger vist at $x$-lyd og e-lyd er begyndt at have overlappende kvalitet, og her er det muligt at vi i næste generation vil se et regulært sammenfald hos et flertal af sprogbrugere, fx af penne, pinde og af kender, kinder (Ejstrup \& Foget Hansen 2003, Juul m.fl. 2016). Det vil betyde at endnu flere vokalstavemåder må knyttes til specifikke ord, så de følger leksikalsk betingede korrespondensregler.

\subsection{Er det blevet svarere at stave?}

Vi har i tabel 3 indsat nogle af de lydudviklinger vi har gennemgået i forudgående afsnit, suppleret med en kolonne der angiver DDO's bud på den etablerede rigsmålsudtale. For nogle af lydforandringerne anser vi udviklingen for så godt som, hvis ikke fuldt, gennemført, dvs. den tidligere udtale findes enten ikke hos dagens dansktalende, eller kun i den $x$ ldste del af befolkningen. For andre er det mere fifty-fifty, dvs. gennemført hos de fleste op til ca. 50-55 år, men ikke nødvendigvis for dem der er ældre. For andre igen er lydudviklingen på vej, eventuelt stærkt på vej i generationerne op til ca. 50. Disse vurderinger skal tages med et gran salt, der er ikke tale om at vi har indsigter fra systematiske studier (som desværre er en mangelvare). Der er heller ikke taget højde for eventuelle regionale faktorer, $\mathrm{fx}$ at talere i Københavnsområdet generelt kan være længere fremme i nyudviklingen end talere uden for Københavnsområdet.

Tabellens eksempler på variation i det danske sprogsamfund giver anledning til både normkonfliktfejl og normhulsfejl: Hvis man staver ud fra den nye udtale, er årsagen en konflikt. Men når en udtaleudvikling er fuldt gennemført, er der så kun hul tilbage som forklaring. Så længe retskrivningen ikke følger trop, vel at mærke. 
TABEL 3. OVERSIGT OVER EKSEMPLER PA LYDUDVIKLINGER OG EN VURDERING AF DERES STATUS

\begin{tabular}{|c|c|c|c|c|}
\hline Type & & Eksempel & Vurdering & DDO \\
\hline Distinkthed & R-tab i prætonisk position & vurdere-vudere & Nok i fremgang. & Har konsekvent $\mathrm{r}[\mathrm{e}]$. \\
\hline Distinkthed & $\begin{array}{l}\text { R-tab efter konsonant og } \\
\text { før schwa-vokal }\end{array}$ & $\begin{array}{l}\text { klatre-klatter } \\
\text { fætre-fætter }\end{array}$ & $\begin{array}{l}\text { Nok i fremgang, højfrekvente } \\
\text { ord (fx højre, venstre, ændre, } \\
\text { andre, mindre) nok mest } \\
\text { tilbøjelige til tab. }\end{array}$ & Har konsekvent r $[$ г $]$. \\
\hline Distinkthed & $\begin{array}{l}\text { Schwa-tab efter konso- } \\
\text { nantgruppe }\end{array}$ & cykle-cykl & På vej i yngste generationer. & $\begin{array}{l}\text { Har konsekvent schwa- } \\
\text { vokal [ə]. }\end{array}$ \\
\hline Lydudvikling & Runding af vokal foran $m$ & $\begin{array}{l}\text { fem-føm } \\
\text { hvem-hvøm }\end{array}$ & $\begin{array}{l}\text { Etableret hos enkeltindivider, } \\
\text { men (stadig) i mindretal. }\end{array}$ & Ingen $ø$-udtaler. \\
\hline Lydudvikling & Vokallængde, forlængelse & $\begin{array}{l}\text { væde-vædde } \\
\text { bure-burre }\end{array}$ & $\begin{array}{l}\text { Gennemført, men ikke i } \\
\text { ældste del af befolkningen. }\end{array}$ & Angiver den $x$ ldre udtale. \\
\hline Lydudvikling & Vokallængde, forkortelse & sorg-sov & $\begin{array}{l}\text { Størst tendens i yngste } \\
\text { generationer. }\end{array}$ & Angiver den ældre udtale. \\
\hline Lydudvikling & $\begin{array}{l}\text { Sammenfald mellem a- og } \\
\text { åben a-vokal efter } r\end{array}$ & $\begin{array}{l}\text { bræt-brat } \\
\text { kræft-kraft }\end{array}$ & $\begin{array}{l}\text { Ikke helt gennemført, } \\
\text { ikke-åben a-vokal stadig i } \\
\text { ældste del af befolkningen. }\end{array}$ & Angiver den $æ$ ldre udtale. \\
\hline Lydudvikling & $\begin{array}{l}\text { Sammenfald af a-og } \\
x \text {-vokal foran } r\end{array}$ & $\begin{array}{l}\text { kære-kager } \\
\text { ære-aet }\end{array}$ & $\begin{array}{l}\text { Ikke helt gennemført, } \\
æ \text {-udtaler stadig i ældste del } \\
\text { af befolkningen. }\end{array}$ & Angiver den ældre udtale. \\
\hline Lydudvikling & R-påvirkning af $i$ - til $e-l y d$ & gris-gres & $\begin{array}{l}\text { Gennemført om 2-3 gene- } \\
\text { rationer. }\end{array}$ & Har konsekvent i-lyd. \\
\hline Lydudvikling & R-påvirkning af $u$ - til $o$-lyd & $\begin{array}{l}\text { rude-rode } \\
\text { russer-rosser }\end{array}$ & $\begin{array}{l}\text { Etableret blandt 40-50-årige } \\
\text { og yngre. }\end{array}$ & Angiver den $æ$ ldre udtale. \\
\hline Lydudvikling & $\begin{array}{l}\text { Sammenfald af } \\
\text { e- og } x-l y d \text { før } n\end{array}$ & $\begin{array}{l}\text { penne-pinde } \\
\text { vende-vinde }\end{array}$ & I sin vorden blandt unge. & Angiver den ældre udtale. \\
\hline
\end{tabular}

Som vist i tabel 3 har de fleste af de udtaleudviklinger der er nævnt i Jørn Lunds artikel fra 1978, så vidt vi kan vurdere, bredt sig yderligere, og nogle af dem er nær ved at være fuldt gennemført i dag. Dertil kommer at der i årtierne siden Lunds artikel er kommet yderligere udtaleudviklinger til (Grønnum 2017, kap. 12). Gennemgangen ovenfor peger således på at antallet af potentielle normhuller er øget betydeligt idet mængden af ord der kan staves ud fra ubetingede korrespondensregler, er blevet mindre, mens antallet af ord der kræver tilegnelse af betingede korrespondensregler, er forøget. Det er helt oplagt blevet sværere at lære at stave eftersom 'pensum' (dvs. antallet af korrespondensregler) er blevet større.

Det er imidlertid ikke sådan at tekster i dag er fyldt med stavefejl der skyldes de udtaleudviklinger vi har nævnt i dette afsnit. Det er ikke svært at finde stavefejl i tekster på sociale medier og netsteder som 
dba.dk hvor sprogbrugere skriver (og staver) om ikke frit fra leveren, så da efter andre normer (se diskussionen om normdannelse på sociale medier i Malai Madsen \& Stæhr 2021: 71-73). Men så vidt vi kan se, er det stadig de mere velkendte stavefejl (se afsnittet om korrespondensregler) der dominerer. Dette stemmer ganske godt med at Jørn Lund i sin artikel understregede at de stavefejl der var "muliggjorte af den lydlige udvikling i moderne dansk" (1978: 178, JL's kursiv), ikke nødvendigvis ville have særlig stor udbredelse.

Også i dag må man formode (desværre er der mangel på undersøgelser der kan belyse sagen empirisk) at de nye flertydigheder primært giver problemer for elever i indskolingen og på mellemtrinnet samt for mindre skriftvante unge og voksne. Det må således retfærdigvis anføres at det ikke er en umulig opgave at lære at stave. Man kan stadig i overvejende grad støtte sig til udtalen når man staver, og knytte de fleste bogstaver til en enkelt lyd. De betingede korrespondensregler er nok vanskeligere at lære end de ubetingede korrespondensregler, men med undervisning og erfaring opbygger de fleste skribenter en stor viden om stavemønstre som de kan trække på (Treiman \& Kessler 2021). ${ }^{14}$

\section{SAMMENFATNING}

I denne artikel har vi givet oversigter på tre områder: en oversigt over mulige årsager til stavefejl og andre afvigelser fra den ortografiske norm, en oversigt over de typer af korrespondensregler man kan støtte sig til hvis man vil lære at stave korrekt, og endelig en oversigt over udtaleudviklinger i moderne dansk der har ændret det udtalemæssige udgangspunkt for sådanne korrespondensregler.

De tre områder vi har beskrevet, behandles ofte hver for sig, men der er vigtige indbyrdes forbindelser imellem dem. For så vidt som rigsmålets udtalenorm breder sig, mens den regionale variation bliver mindre, kan man formode at regionalt betingede normkonflikter i dag er en mindre fremtrædende årsag til stavefejl end tidligere. På den anden side

14 I denne forbindelse er det værd at bemærke at sprogbrugere fra dialektprægede områder på grund af normkonflikter har (eller har haft) en ekstra opgave i forhold til rigsmålstalende, men at dette, så vidt det er belyst, ikke betyder at deres tekster er præget af flere stavefejl. Selv i et materiale fra 1940 'erne, hvor dialekterne stod langt stærkere end i dag, blev der kun fundet ret beskedne regionale forskelle i beherskelsen af retskrivningsnormen (Noesgaard 1945, se også Lund 1984). 
har andre udtaleudviklinger i moderne dansk medført mange nye potentielle normkonflikter. Disse normkonflikter kan overvindes ved at man tilegner sig viden om konservative rigsmålsudtaler (evt. læseudtaler), men hvis udgangspunktet for staveundervisning skal være dansk som det tales i dag, giver udtaleudviklingerne i moderne dansk snarere anledning til at fokusere på flere betingede korrespondensregler. Undlades dette, forøges risikoen for normhuller - som når den tryksvage endelse [ $\mathrm{k}$ ] både kan staves er, rer, rrer, re og rre (jf. afsnit 4 ovenfor).

Endelig kan man formode at antallet af fejl der skyldes normsammenbrud (herunder slåfejl), i dag er blevet større i takt med at flere tekster skrives og publiceres uden om de traditionelle gatekeeperes kontrol (redaktører, korrekturlæsere osv.). På den anden side er disse gatekeepere til dels erstattet af elektroniske hjælpemidler i form af stavekontrol og ordforslag. Både de menneskelige og elektroniske dørvogtere har dog deres begrænsninger. Selv i nyhedsstrømmen på dr.dk vil man kunne støde på eksempler på stavefejl som må være sluppet forbi både den elektroniske stavekontrol og en redaktør.

\section{KAN DET BLIVE LETTERE AT STAVE?}

Vi har igennem denne artikel fokuseret på vanskelighederne ved at stave. Men kan det blive lettere at stave? Her vil vi afslutningsvis pege på tre muligheder.

For det første kan man mindske afstanden mellem udtaleformer og stavemåder - enten ved at tale mere bogstavnært eller ved at tilpasse retskrivningen til moderne udtale. Det første forekommer at være et tvivlsomt projekt, men historisk er der mange eksempler på at læseudtaler er blevet normen (Pedersen 2017), og vi ser visse tendenser i den retning når det eksempelvis er blevet almindeligt at udtale $b$ 'et i $k ø b$ mand og $d$ et i snedker, men dette er detaljer i det store billede.

Retskrivningsreformer er et sprogpolitisk område hvor opinionen generelt har været imod større ændringer, mens især sprogforskere med jævne mellemrum slår til lyd for tilpasninger til udtalen (Rask 1826, Olander 2002, Gregersen 2005; se også Basbøll 2021 og diskussionen hos Becker-Christensen 2021: 71-75). I tidens løb er der dog sket ganske mange tilpasninger af normen, hvad man kan forvisse sig om ved at gå på opdagelse på Dansk Sprognævns retskrivningshistoriske netsted 
rohist.dk og i Galberg Jacobsens retskrivningshistorie (Jacobsen 2010; se også Becker-Christensen 2021: 53-62 for en kort oversigt). Det er dog tankevækkende at de tilpasninger der er gennemført med størst succes, ikke har været motiveret af udtaleændringer, men har været forenklinger af korrespondensreglerne, dvs. imødekommelser af det pædagogiske princip - $\mathrm{fx}$ substantiver stavet med lille begyndelsesbogstav (jf. Dag og Nat > dag og nat siden 1948) og j-lyd stavet $j$ i linje, tredje, hvor man før skrev $i$. Man bør dog efter vores opfattelse fortsat overveje om man kan spare skolelever og andre sprogbrugere for besvær ved at gennemføre mere gennemgribende reformer, $\mathrm{fx}$ baseret på det pædagogiske princip, eller ved at øge accepten af ortografisk variation.

For det andet kan man forbedre yderligere på de sprogteknologiske hjælpemidler i form af stavekontroller, ordforslagsprogrammer og taletil-tekst-software, der i højere grad har indarbejdet viden om udtalemæssig variation. Der er på det teknologiske område sket store fremskridt, og disse udnyttes i stigende grad pædagogisk (Engmose 2019, Tinggaard \& Fredsø-Rauer 2021). Men endnu er vi meget langt fra en situation hvor den enkelte sprogbruger ikke længere har behov for at kunne stave på egen hånd.

Dermed ender vi med den tredje og sidste mulighed, som er mere effektiv staveundervisning. En gennemgånde pointe i denne artikel har været at solid viden om udtale og udtalevariation er af stor betydning, for ikke at sige uomgængeligt, for staveundervisere, både når de skal fortolke stavefejl, og når de skal opstille korrespondensregler med udgangspunkt i deres elevers udtale. Når man ser bort fra oplagte slåfejl, er langt de fleste stavefejl lydbevarende (jf. eksemplerne i afsnit 2.2.2), hvilket viser at skribenter i høj grad bygger på udtalen når de staver. Ordenes lyde fungerer som en slags knagerække som bogstaverne kan hænges op på - og uden denne knagerække bliver det langt sværere at huske hvilke bogstaver der indgår i ord og i hvilken rækkefølge (Ehri 2014). Staveundervisere bør derfor både kende deres elevers udtalemæssige 'knagerække' og kunne vurdere hvilke korrespondensregler de har brug for at hænge op på den. I betragtning af hvor svær den danske retskrivning er at lære, og hvor mange resurser der bruges på staveundervisning, er det en besynderlighed at næsten alle undersøgelser af stavning har haft fokus på forekomsten af forskellige fejltyper 
- hvorimod næsten ingen danske undersøgelser har undersøgt effekten af staveundervisning (Juul 2020).

Vi vil slutte dette overblik over forhold med betydning for stavefejlsanalyse med et håb om at der i fremtiden bliver færre fejl at analysere på. Hvis retskrivningsreformer, teknologiske landvindinger og forbedrede undervisningsmetoder går op i en højere enhed, kan det saktens blie marred mintrer sverdt å stagve.

Holger Juul, lektor

Institut for Nordiske Studier og Sprogvidenskab

Københavns Universitet

juul@hum.ku.dk

Jan Heegård Petersen, lektor

Institut for Nordiske Studier og Sprogvidenskab

Københavns Universitet

janhp@hum.ku.dk

\section{LITTERATUR}

Andersen, M.H. 2016. Sprognormer på nettet. I.S Hansen, T.T. Hougaard \& K. Thisted Petersen, 16. Møde om Udforskningen af Dansk Sprog, 75-90. Århus: Nordisk, Institut for Kommunikation og Kultur, Aarhus Universitet.

Basbøll, H. 2021. Radikal ortografi og/eller lydskrift? Nogle eksempler fra Rasmus Rask og J.H. Bredsdorff. J. Bjerring-Hansen, S. Skovgaard Boeck, \& E. Skafte Jensen (red.), Nogle betenkninger om dansk sprog og litteratur: Festskrift til Marita Akhøj Nielsen 295-313.

Becker-Christensen, C. 2021. Dansk retskrivning. Bogstav - Lyd - Bogstav (Dansk Sprognævns skrifter 51). Odense: Syddansk Universitetsforlag.

Bjerre, A. \& J. Friis. 2002. Nej Farfar! for vi børnestaver. København: Alinea.

Brink, L. 2000. Om den sproglige forskel mellem Hansen-a og Larsen-a. Mål \& Male 23(1). 17-22.

Brink, L. 2021. Nytydeliggørelse. M.H. Andersen \& E.S. Jensen (red.), Med fornøden agtelse. Festskrift til Jørgen Schack på 60-årsdagen 14. maj 2021. (Dansk Sprognævns skrifter 52), 33-41. Bogense: Dansk Sprognævn.

Brink, L. \& J. Lund. 1975. Dansk rigsmål. Lydudviklingen siden 1840 med sarligt henblik på sociolekterne i København. København: Gyldendal. 
Brink, L. \& J. Lund. 2019. Yngre nydansk. E. Hjorth (hovedred.), Dansk sproghistorie, (bind 2), Ord for ord for ord, 197-228. Aarhus og København: Aarhus Universitetsforlag \& Det Danske Sprog- og Litteraturselskab.

Brink, L. m.fl. (red.) 1991. Den store danske udtaleordbog. København: Munksgaard.

Christiansen, G. 1980. Degte på dansg. København: Københavns Bogforlag.

Dansk Sprognævn. 2012. Retskrivningsordbogen, 4. udg. København: Alinea.

Davidsen-Nielsen, N. \& M. Herslund. 2013. Principia orthographica. NyS, Nydanske Sprogstudier 44. 10-30. DOI: 10.7146/nys.v44i44.14355.

Detlef, C., J. Lund \& L. Møller. 1986. Stavning: dansk retskrivning - retskrivning $i$ dansk. København: Dansklærerforeningen.

Diderichsen, P. 1968. Sprogsyn og sproglig opdragelse. København: Nyt Nordisk Forlag Arnold Busck.

Diderichsen, P., S.J. Christensen \& J. Schack. 2020. Ortografisk rangering - at ordne tekster efter antallet af stavefejl. Studier i Nordisk 2012-2015. 61-85.

Ehri, L.C. 2014. Orthographic mapping the acquisition of sight word reading, spelling memory, and vocabulary learning. Scientific Studies of Reading 18(1). 5-21. DOI: $10.1080 / 10888438.2013 .819356$.

Ejstrup, M. \& G. Foget Hansen. 2003. Danish vowels in spontaneous speech in three modern regional variants. Proceedings of the 15th International Congress of Phonetic Sciences, Barcelona 2003. 2119-2122.

Elbro, C. 2014. Lasning og leseundervisning. København: Hans Reitzel.

Elbro, C. 2021. Lasevanskeligheder. København: Hans Reitzel.

Elbro, C., P.F. de Jong, D. Houter \& A-M. Nielsen. 2012. From spelling pronunciation to lexical access: A second step in word decoding? Scientific Studies of Reading 16(4). 341-359. DOI: 10.1080/10888438.2011.568556.

Engmose, S.F. 2019. (IT)-støttet børnestavning: studier af børnestavnings rolle i den tidlige skriftsproglige udvikling. Ph.d.-afhandling. Københavns Universitet.

Frederiksen, B.O. 2019. Gammeldansk. E. Hjorth (hovedred.), Dansk sproghistorie (bind 2): Ord for ord for ord. 27-55. Aarhus og København: Aarhus Universitetsforlag og Det Danske Sprog- og Litteraturselskab.

Gregersen, F. 1981. Hvorfor skriver vi nd og ld: et bidrag til skriftens socialhistorie i Danmark. SAML 8. 113-178.

Gregersen, F. 1983. Anmeldelse af Erik Hansen: Skrift, stavning og retstavning // Ulf Teleman: Ret og rimeligt. Om skolens og samfundets sprognormer. Nydanske sprogstudier, NyS. 13 75-94. DOI: https://doi.org/10.7146/nys.v13i13.13329. 
Gregersen, F. 2005. Hvorfor ikke ændre dansk retskrivning? Mål \& Male 28(3-4). 20-22.

Grønnum, N. 2000. Et kort a i dansk: en mere abstrakt analyse. Mål \& Mæle 23(2). $14-19$.

Grønnum, N. 2007. Rødgrød med fløde. En lille bog om dansk fonetik. København: Akademisk Forlag.

Gymnasiekontoret. 2020. Dansk A, stx. Vejledning. Børne- og Undervisningsministeriet. Styrelsen for Undervisning og Kvalitet.

Hansen, Aa. 1967. Moderne dansk, bind 1. København: Det Danske Sprog- og Litteraturselskab \& Grafisk Forlag.

Hansen, E. 1980. Hvad er en stavefejl?. Mål \& Male 7(1). 18-24.

Hansen, E. 1993. Rigtigt dansk. København: Hans Hans Reitzels forlag.

Hansen, E. 1999. Skrift, stavning og retstavning. København: Hans Reitzel.

Hauerberg Olsen, M. 1998. Bogstaveligt. En grundbog i fonetik og fonologi for undervisere $i$ stavning og lasning. Frederiksberg: Samfundslitteratur.

Heegård Petersen, J., m.fl. 2021. Udtalt: en introduktion til dansk fonetik. Frederiksberg: Samfundslitteratur.

Holsting, A. m.fl. 2021. Hvad retter de? Nyindskrevne studerendes revision af universitetsopgaver. NyS, Nydanske Sprogstudier 59. 157-186. DOI: https://doi. org/10.7146/nys.v1i59-60.126121.

Jacobsen, H.G. 2010. Ret og skrift: officiel dansk retskrivning 1739-2005, bind 1. Direktiver, aktører, normer. Odense: Syddansk Universitetsforlag.

Jervelund, A.Å. 2007. Sådan staver vi: om ortografi og stavefejl. København og Frederiksberg: Dansklærerforeningen og Dansk Sprognævn.

Juul, H. 2003. Typer af stavefejl og typer af stavefærdighed. Danske Talesprog 4. 59-74.

Juul, H. 2005. Grammatical awareness and the spelling of inflectional morphemes in Danish. International Journal of Applied Linguistics 15(1). 87-112.

Juul, H. 2012. Udtaledistinkthed og stavefærdighed hos danske børn. Danske Talesprog 12. 96-109.

Juul, H. 2016. Hvornår er et ord lydret? Kognition \& padagogik 99. 40-54.

Juul, H. 2019. Vejledning til staveprøve 1-3. Virum: Hogrefe Psykologisk Forlag.

Juul, H. 2020. Om effekten af at undervise i stavning. https://www.videnomlaesning. $\mathrm{dk} /$ viden-og-vaerktoejer/forskerklummen/2020/om-effekten-af-at-undervise -i-stavning/. 
Juul, H. \& C. Elbro. 2004. The links between grammar and spelling. A cognitive hurdle in deep orthographies? Reading and Writing: An Interdisciplinary Journal 17. 915-942.

Juul, H., N. Pharao \& J. Thøgersen. 2016. Moderne danske vokaler. Danske Talesprog 16. 33-72.

Juul, H. \& D.K. Petersen. 2017. Length effects pseudo-word spelling: stronger dyslexic than non-dyslexic students. Annals of Dyslexia 67. 369-382. DOI: 10.1007/ s11881-017-0149-3.

Juul, H. \& B. Sigurðsson. 2005. Orthography as a handicap? A direct comparison of spelling acquisition in Danish and Icelandic. Scandinavian Journal of Psychology 46. 263-272.

Kristiansen, T. 1990. Udtalenormering $i$ skolen: skitse af en ideologisk bastion. København: Gyldendal.

Larsen, A. \& A.C. Stæhr. 2020. Afdialektificering på Bornholm - det sidste stadie? Danske Talesprog 20. 195-221.

Lund, J. 1978. Atte bleddet svagere og stagve? Lasepadagogen 26(4). 178-202.

Lund, J. 1984. Den danske skole og dialekterne. En studie i sejlads uden ror. Språk i Norden 1984. 19-35.

Lund, J. 1985. Egernerne, søskendene og de mangehovedede uhyrer. Om strukturparallellisme. Nyt fra Sprognavnet 2. 1-3.

Malai Madsen, L. \& A.C. Stæhr. 2021. Sociale medier - Standardsvækkelse og sprolig liberalisering? T. Kristiansen \& A. Holmen (red.), Sprogs status i rigsfallesskabet 203 (Københavnerstudier i tosprogethed, bind C13), 64-78. København: Københavns Universitet.

Monka, M. 2018. Sociolingvistik - Dialektbrug på tværs af online- og offlinekontekster. A.C. Stæhr \& K.K. Mortensen (red.), Sociale medier og sprog: analytiske tilgange, 29-59. Frederiksberg: Samfundslitteratur.

Møller, L. \& H. Juul. 2017. Skriftsproglig udvikling - fra 12 år: vejledning, Virum: Hogrefe Psykologisk Forlag.

Mørch, I.E. 2014. Korrekt stavning. Underviserens håndbog i dansk retskrivning. Frederikshavn og København: Dafolo og Dansk Sprognævn.

Noesgaard, A. 1945. Fejltyper i dansk retskrivning. København: Udvalget for skolepsykologiske undersøgelser. 
Olander, T. 2002. Tañgw wm dänqsg radsgrivneñ / Tanker om dansk retskrivning. A. Hyllested, A.R. Jørgensen, J.H. Larsson \& T. Olander (red.), Festskrift til Birgit Anette Olsen på 50-årsdagen den 2. april 2002, 85-88. København: Ediciones Olander.

Olander, T. 2019. Oversigt over det danske lydsystem. Version 0.6. https://www.sproghistorie.dk/lydsystem/index-dansk.php. (Sidst tilgået 20. november 2021).

Pallesen, B.R. 1999. Om distinkthed. Mål og Male 22(2). 17-21.

Pedersen, I.L. 2017. Luthers indflydelse på det danske talesprog gennem 300 år. Danske talesprog. 44-75.

Pharao, N. 2010. Consonant reduction in Copenhagen Danish: a study of linguistic and extra-linguistic factors phonetic variation and change. Ph.d.-afhandling. Københavns Universitet.

Rask, R. 1826. Forsøg til en videnskabelig dansk Retskrivningslare med Hensyn til Stamsproget og Nabosproget. Tidskrift for nordisk Oldkyndighed, bind 1.

Rathje, M. 2013. "sku allgvel ha købt penis forlænger creme :-)". Afvigelser fra retskrivningsnormen i kommentarfeltet på ekstrabladet.dk. 14. I.S. Hansen, T.T. Hougaard og P. Widell (red.), Møde om Udforskningen af Dansk Sprog, 333-354. http://muds.dk/rapporter/MUDS_14.pdf (sidst tilgået 11. januar 2022).

Rathje, M. 2019. Afvigelser fra retskrivningsnormen i universitetsopgaver. 17. Y. Goldshtein, I.S. Hansen og T.T. Hougaard (red.), Møde om Udforskningen af Dansk Sprog, 415-437. https://projekter.au.dk/fileadmin/projekter/Muds.dk/ rapporter/Muds_17.pdf (sidst tilgået 11. januar 2022).

Schachtenhaufen, R. 2009. Hvad rimer på gris?. https://schwa.dk/vokaler/hvad-rimerpa-gris/. (Sidst tilgået 20. november 2021).

Schachtenhaufen, R. 2011. Hvad ved børn om schwa? http://schwa.dk/fonologi/hvadved-b\%c3\%b8rn-om-schwa/.

Schachtenhaufen, R. 2013. Fonetisk reduktion i dansk. Ph.d-afhandling. Copenhagen Business School.

Schack, J. \& A.Å. Jervelund. 2016. Den der skriver d i gjort: staveproblemer i folkeskolens aldste klasser. Frederiksberg: Dansk Sprognævn.

Schelde, M.K. 2018. Kakao rimer på mave. Må \& Male 39(2). 17-21.

Sørensen, V. 2007. Når forfatterne skriver jysk: og hvad det fortæller om skriftsprog og lydskrift. Ord \& sag 27. 44-61. http://www.jysk.au.dk/publikationer/oversigt/ ordsag/ordsag27.pdf. (sidst tilgået 11. januar 2022). 
Teleman, U. 1981. Ret og rimeligt: om skolens og samfundets sprognormer. København: Hans Reitzel.

Thøgersen, J. 2012. Vil De prøve at sige A?: "fladt a" i Radioavisen 1950-2010. NyS, Nydanske Sprogstudier 43. 101-132. DOI: https://doi.org/10.7146/nys. v43i43.14347.

Tinggaard, M.K. \& J. Fredsø-Rauer. 2021. Fra beg*ing til begejstring - giv elever med ordblindhed et stabilt fundament af stavestrategier. Lasepadagogen 69(3). 4-9.

Treiman, R. \& B. Kessler. (Førtryk). Statistical learning word reading and spelling across languages and writing systems. Scientific Studies of Reading. DOI: 10.1080/10888438.2021.1920951.

Uddannelsesstyrelsen. 2002. Hvordan staver studenterne?: en undersøgelse af stavefejl $i$ studentereksamensstilene 1998. København: Undervisningsministeriet.

Westergaard, A. 2014. Om sammenhængen mellem sprogvalg og kommunikativ rækkevidde på Facebook. NyS, Nydanske Sprogstudier 46. 172-208. DOI: 10.7146/ nys.v46i46.17528. r

\section{HJEMMESIDER}

Bogstavlyd: https://bogstavlyd.ku.dk/forside/

DDO (Den Danske ordbog). u.å. : https://ordnet.dk/ddo/forside (tilgået xxx).

RO (Retskrivningsordbogen): https://roplus.dk/\#ordbog/

ROhist (Retskrivningsordbøger gennem historien): https://rohist.dsn.dk/ 